\title{
LA INDEPENDENCIA DEL PODER JUDICIAL EN LA HISTORIA CONSTITUCIONAL ESPAÑOLA.
}

\section{INDEPENDENCE OF THE JUDICIAL POWER IN SPANISH CONSTITUTIONAL HISTORY.}

\author{
Jorge Pérez Alonso \\ Seminario Martínez Marina de Historia Constitucional \\ (Universidad de Oviedo)
}

\section{A la memoria de mi maestro Joaquin Varela Suanzes-Carpegna, con inmensa gratitud por sus enseñanzas y su amistad.}

I.- INDEPENDENCIA JUDICIAL Y ESTADO DE DERECHO. 1.1.- La necesidad de un Poder Judicial independiente. 1.2.- La independencia judicial. 1.3. La influencia del contexto en la independencia judicial. II.- REGULACIÓN CONSTITUCIONAL DE LA INDEPENDENCIA JUDICIAL EN EL SIGLO XIX. 2.1.$\mathrm{La}$ independencia judicial en los orígenes del constitucionalismo. 2.1.1.- La Constitución de Bayona. 2.1.2.- La Constitución de Cádiz. 2.2.Constitucionalismo y poder judicial en la era isabelina. 2.2.1 Independencia del poder judicial en los textos constitucionales. 2.2.2.- La realidad: injerencia del ejecutivo en el poder judicial III.- DOS INTENTOS DE PRESERVAR LA INDEPENDENCIA JUDICIAL: $1873 \mathrm{Y}$ 1923. 3.1.- El fugacísimo precedente de 1873. 3.1.1.- Los hitos normativos del sexenio democrático: Constitución de 1869 y Ley de 15 de septiembre de 1870. 3.1.2.- El Decreto Salmerón de 8 de mayo de 1873. 3.1.3.- El Proyecto de Constitución Federal de la República española. 3.1.4.- El regreso al sistema tradicional 3.2.- La Junta Organizadora del Poder Judicial de 1923. 3.2.1.- El advenimiento de la Dictadura. 3.2.2.- El Decreto de 2 de octubre de 1923. 3.2.3.- El Decreto de 20 de octubre de 1923. 3.2.4.Funcionamiento del sistema. 3.2.5.- El final de la experiencia: el Consejo Judicial de 1926. IV.- SEGUNDA REPÚBLICA Y PODER JUDICIAL. V.- EL AUTOGOBIERNO DE LOS JUECES EN LA CONSTITUCIÓN DE 1978: EL CONSEJO GENERAL DEL PODER JUDICIAL. 5.1.- Modelos constitucionales existentes. 5.2. Del Anteproyecto al Texto Constitucional de 1978. 5.2.1.- El Anteproyecto y su tramitación en el Congreso de los Diputados. 5.2.2. El Anteproyecto en el Senado. 5.3.- Breve referencia a la evolución posterior. V.CONCLUSIÓN

Resumen: En 1978, la Constitución española creó el Consejo General del Poder Judicial en un intento de lograr la independencia de la judicatura. A lo largo de los siglos diecinueve y veinte, los preceptos constitucionales relativos al poder judicial fracasaron porque, en la práctica, el ejecutivo se entrometió en el judicial ejercitando las facultades de destitución. Tan solo en dos breves periodos (unos meses en 1873 y tres años entre 1923 y 1926) hubo un verdadero intento de establecer un autogobierno judicial. El presente artículo aborda la regulación del poder judicial en nuestra historia constitucional así como su funcionamiento en la práctica. 
Abstract: In 1978, Spanish Constitution established Judicial Power General Council in an attempt to achieve the independence of the judiciary. During nineteenth and twentieth centuries, constitutional provisions dealing with the Judicial power were a complete failure, because in practice Executive power interfered with the judiciary exercing removal power. Only in two short periods (a few months in 1873 and three years between 1923 and 1926) there were true attempts to establish a real judicial selfgovernment. This article approaches the provisions dealing with Judicial power in our constitutional history and their operation in practice.

Palabras clave: Constitución - Poder Judicial

Key Words: Constitution - Judicial Power

\section{I.- INDEPENDENCIA JUDICIAL Y ESTADO DE DERECHO.}

\section{1.- La necesidad de un Poder Judicial independiente}

En diciembre del año 2006, en una conversación con varios alumnos de diversas high schools, el actual chief justice, John G. Roberts jr, señalaba la importancia decisiva que poder judicial tiene en un sistema regido por los principios del estado de Derecho: "If you have a system that is governed by the rule of law, you need to have someone to tell you what the law is". Añadia también que a la hora de implantar la democracia en los paises: "one of the hardest things to do is to establish independent courts." 1 De forma tan didáctica y sencilla, el máximo responsable de la judicatura federal estadounidense indicaba los dos aspectos necesarios e imprescindibles para la efectividad de un sistema que pretenda ser considerado un estado de Derecho: poder judicial independiente (como intérprete de las normas y como encargado de controlar y servir de freno y contrapeso a los otros dos) y dificultad de articular jurídicamente esa independencia. Y es que, como de forma muy acertada ha indicado en fechas recientes Alejandro Nieto, "un poder judicial sin independencia no es poder, puesto que no puede controlar al Gobierno, que es la última garantía del sistema constitucional: el controlador no puede, por tanto, depender del controlado. Y para que una institución sea independiente es imprescindible que lo sean sus miembros." 2

John Roberts manifestaba en otro momento de su intervención el orgullo que suponía para los Estados Unidos descender de una tradición, la inglesa del common law, que desde tiempo atrás había definido claramente el papel de los tribunales. Bien es cierto que, aun cuando John Locke, en su Segundo tratado sobre el Gobierno civil, no consideraba al judicial como uno de los tres poderes, ello se debía más que nada a las funciones que los jueces efectuaban, y no a su dependencia o sujeción a otro poder. Pero la idea de que los órganos judiciales no estaban sometidos ni a los dictados del Parlamento ni a las órdenes monarca se encontraba tan sólidamente arraigada en suelo inglés desde hacía tiempo, que

1 La intervención de John G. Roberts es accesible a través de internet en el enlace https://www.youtube.com/watch?v=fRoNWcgzluQ.

2 Alejandro NIETO, Testimonios de un jurista (1930-2018), Global Law Press-INAP, 2018, p. 199 
buena prueba de ello lo tenemos en un curiosísimo episodio histórico: el enfrentamiento que el 13 de noviembre de 1608 tuvo lugar entre el rey Jacobo I de Inglaterra y el juez inglés Sir Edward Coke. Cuando aquel trató de avocar para sí el conocimiento de cualquier asunto que estuviese tramitando un órgano judicial, el célebre jurista inglés se opuso a las pretensiones del monarca, argumentando que:

"the King in his own person cannot adjudge any case...but that this ought to be determined and adjudged in some Court of Justice, according to the law and custom of England [...] true it was that God has endowed His Majesty with excellent science, and great endowments of nature [...] His Majesty was not learned in the laws of his realm of England, and causes which concern the life, or inheritance, or goods, or fortunes of his subjects, are not to be decided by natural reason but by the artificial reason and judment of law, which law is an act which requires long study and experience, before that a man can attain to the cognisane of it: that the law was the Golden-wand and measure to try the causes of the subjects" 3 .

Esa concepción británica de los órganos judiciales, se trasplantó ulteriormente a las colonias británicas en Norteamérica, que la recogieron y asumieron como propia. No obstante, tras el proceso independentista y, sobre todo, en la Convención constitucional de 1787, quedó explicitada una diferencia fundamental respecto a la antigua madre patria, diferencia que se encargó de resaltar el anónimo autor oculto bajo el seudónimo Brutus en el decimoquinto ensayo antifederalista publicado el día 20 de marzo de 1788:

"The judges in England are under the control of the legislature, for they are bound to determine according to the laws passed by them. But the judges under this constitution will control the legislature, for the supreme court are authorised in the last resort, to determine what is the extent of the Powers of the Congress." 4

En definitiva, según las tesis sustentadas por Brutus, los jueces estadounidenses, al ostentar la facultad del control constitucional de las leyes o judicial review ${ }^{5}$, podían mediatizar la labor del legislativo, lo que les haría independientes en el sentido literal del término ${ }^{6}$. Y aun cuando a lo largo de la

3 Bernard SCHWARTZ, A history of the Supreme Court, Oxford University Press, 1993, p. 3-4. Es altamente significativo que dicho autor principie la historia del Tribunal Supremo de los Estados Unidos utilizando como punto de partida el enfrentamiento entre Coke y Jacobo I.

${ }^{4}$ La cita se extrae de la recopilación documental contenida en Debates on the Federal Judiciary, Volume I, Federal Judicial Center, 2013, p. 30.

$5 \mathrm{El}$ reconocimiento por Brutus ya en 1788 que los jueces poseían la facultad de judicial review implica que no fue el caso Marbury el que estableció dicha potestad. No podemos, pues, más que coincidir con la afirmación del juez Byron White, quien en un memorándum dirigido al entonces chief justice Warren E. Burger en pleno proceso de deliberación interna del caso United States $v$. Nixon, se oponía a la tesis tradicional asumida por Burger en el sentido que fue la sentencia MArbury la que creó dicho principio, tesis que refutaba con las siguientes palabras: "Because I am one of those who thinks that the Constitution on its face provides for judicial review, especially if construed in the light of what those who drafted it said at the time or later, I always wince when it is inferred that the Court created or even when it is said that the "power of judicial review [was] first announced in Marbury v. Madison"...But perhaps this is only personal idiosyncrasy,"; Bernard SCHWARTZ, Unpublished opinions of the Burger Court, Oxford University Press, 1988, p. 279

$6 \mathrm{El}$ encargado de refutar las tesis de Brutus no fue otro que Alexander Hamilton, quien lo hizo encubierto bajo el seudónimo Publius en el célebre septuagésimo octavo ensayo de los Federalist papers. 
historia norteamericana hubo notables intentos de someter al poder judicial a la voluntad de otros (el impeachment de Samuel Chase $^{7}$ o el Court Packing Plan auspiciado por Franklin Roosevelt ${ }^{8}$ ), en general tales intentos fracasaron, reforzando con ello la independencia de los integrantes del poder judicial.

En el continente europeo, la situación fue harto distinta, y en particular en España, donde el absolutismo a ultranza que se implantó en la edad moderna, así como la debilidad del desarrollo de la burguesía como contrapeso al estamento nobiliario, no fue muy propicio para el establecimiento de una judicatura independiente. A dicha circunstancia se añade otra no menos decisiva: no ya al instaurarse, sino al consolidarse definitivamente el constitucionalismo, no se consideró al poder judicial como independiente, lo cual, unido a una larga y tétrica historia de ceses, purgas y remociones en la magistratura, llevó en muchos casos a la sumisión más absoluta respecto de los otros dos poderes. Tal situación acabará provocando un desequilibrio institucional, una descompensación que, como bien indica Diego Íñiguez Hernández, puede dar lugar a una curiosa paradoja en los: "sistemas juridicos continentales, en los que el juez ha tenido históricamente un papel muy secundario $y$ cuyos frenos $y$ contrapesos han sido siempre débiles, cuando no inexistentes. El poder politico ha tendido a concentrarse en el Ejecutivo o el Legislativo - "en cuanto representante de la voluntad popular." Pero cuando se desarrollan las condiciones para el fortalecimiento del judicial, éste llega a ser más fuerte, y faltando un sistema eficaz de contrapesos, resulta que deja de estar contrapesado."9

Lo expuesto en los párrafos anteriores nos lleva ya a anticipar que la situación ni era, ni continúa siendo precisamente muy halagüeña en lo que a la independencia del poder judicial se refiere. En los últimos años, con el objetivo de concienciar a la opinión pública de la peligrosísima situación que actualmente afronta la judicatura, han aparecido diversos libros-denuncia, algunos de ellos con titulos altamente significativos que evidencian la gravedad extrema del asunto $^{10}$. Pero tales obras han sido cubiertas con un doloso y elocuente manto de

7 Samuel Chase era uno de los jueces del Tribunal Supremo de los Estados Unidos, nombrado en enero de 1796 a propuesta de George Washington. Partidario federalista y con un genio muy vivo, era conocido con bacon old face. Cuando Thomas Jefferson fue elegido presidente, tuvo un sonoro enfrentamiento con el Tribunal Supremo, presidido por John Marshall, de quien era primo lejano. Para intimidar a los jueces, promovió un impeachment frente a Samuel Chase, con la finalidad de que sirviera de aviso a navegantes. El Senado, presidido por el no menos célebre Aaron Burr, no hizo caso a Jefferson y absolvió a Chase. Un análisis de este acontecimiento lo encontramos en William REHNQUIST, Grand Inquests: The historic impeachments of Justice Samuel Chase and President Andrew Johnson, Alfred A. Knopff, 1992.

8 Ante pronunciamientos judiciales adversos a las reformas legislativas auspiciadas por Roosevelt en aplicación de su New Deal, el presidente impulsó un proyecto que alteraba la composición del Tribunal Supremo, permitiéndole aumentar el número de jueces y designar para dicho órgano a personas comprometidas con su proyecto. El propio Partido Demócrata, al que pertenecía Roosevelt, rehusó apoyar una medida tan descaradamente motivada por criterios políticos, de ahí que el intento naufragó en el más estrepitoso de los fracasos. El lector interesado puede consultar la magnífica crónica de Jeff SEHSOL, Supreme Power: Franklin Roosevelt vs. The Supreme Court, W.W.W. Norton \& Company, 2011.

9 Diego ÍÑIGUEZ HERNÁNDEZ, El fracaso del autogobierno judicial, Aranzadi, 2008, p. 51.

10 Cito tan sólo cuatro títulos que me parecen altamente reveladores. Al ya citado de Diego Íñiguez Hernández cabe añadir el de José Luís REQUERO IBÁÑEZ, El asalto a la Justicia. La última barrera ante el totalitarismo, Ciudadela Libros S.L., 2009; Jesús VILLEGAS FERNÁNDEZ, El poder amordazado, Península, 2016; Francisco SOSA WAGNER, La independencia del juez, ¿una 
silencio, tanto por los poderes públicos como por los medios de comunicación que, salvo contadas y honrosísimas excepciones, han preferido refugiarse en la técnica del avestruz que asumir el doloroso trance de emprender un viaje iniciático que implica un descenso a los avernos.

\section{2.- La independencia judicial.}

Debemos plantearnos, con carácter previo, un interrogante: qué debe entenderse por "independencia judicial".

Diego Íñiguez Hernández resume en el siguiente párrafo las funciones de la independencia judicial en un estado de Derecho:

"En primer lugar, la independencia respecto a las partes es una condición necesaria para garantizar la imparcialidad del juez. En segundo lugar, un juez independiente supone un limite eficaz al modo en que se desempeñan las funciones públicas $y$, en definitiva, el poder. En tercer lugar, como la magistratura ya no está aislada de su entorno politico, el juez desempeña un papel fundamental en los regímenes democráticos, lo que implica inevitablemente la aparición de tensiones con el sistema político."11

En suma, el concepto de independencia debe orientarse en dos direcciones o caminos opuestos: ad intra, es decir, la que se predica de los miembros de la judicatura a la hora de resolver un proceso concreto; y ad extra, frente a las intromisiones y agresiones de los otros dos poderes ${ }^{12}$.

En el primer caso, es decir, la independencia del juez respecto a las partes en conflicto, se vincula a la neutralidad e imparcialidad que ha de ostentar la persona que, en su condición de árbitro o mediador, ha de resolver el conflicto entre dos partes en liza. La misma no suele plantear excesivos problemas, puesto que procesalmente se garantiza a través de la garantía del juez ordinario predeterminado por la ley y el establecimiento de mecanismos de abstención y recusación puestos a disposición tanto de las partes como del propio juez cuando éste tiene interés en el asunto o relación con alguna de las partes. Se trata, por tanto, de garantizar que los jueces y magistrados actúan en el desarrollo de sus funciones con plena imparcialidad. Bien es cierto que la propia ideologia del juez, inconscientemente se puede proyectar no sólo a la hora de resolver un asunto, sino al tratamiento de las propias partes en disputa. Pero en líneas generales no es este el aspecto más delicado de la cuestión.

La segunda de las implicaciones que el concepto entraña, es decir, la relación del poder judicial con el legislativo y el ejecutivo, es ya bastante más compleja y delicada. En este sentido se trata de verificar cómo se articula constitucionalmente la división de poderes para garantizar la que el judicial no vea comprometido el ejercicio de su función por la intervención de los otros dos poderes. Se trata, por tanto, de garantizar no sólo la independencia del poder

fábula?, La esfera de los libros, 2016. Dos de los autores citados (José Luís Requero y Jesús Villegas) son, además, jueces en activo, por lo que su narración es quizá más vívida y acentuada en su dramatismo, en cuanto contemplan las disfunciones del sistema desde dentro, siendo el ensayo del último de los autores citados una verdadera llamada de auxilio.

11 Diego ÍÑIGUEZ HERNÁNDEZ, El fracaso del autogobierno judicial, op. cit., p. 52

12 Diego ÍNIIGUEZ HERNÁNDEZ, El fracaso del autogobierno judicial, op. cit., p. 58 
judicial stricto sensu, sino de sus propios integrantes, es decir, de los jueces, lo cual reconduce a las garantias que constitucionalmente se contemplan para hacer efectiva dicha independencia ${ }^{13}$, que en gran medida se sustentan tanto en la inamovilidad del cargo como en la protección frente a injerencias indebidas de los otros dos poderes. Francisco Sosa Wagner resume de la siguiente forma tan certera como desenfadada el núcleo básico de la independencia judicial:

"incluye, de un lado, ingredientes sustantivos, como son el nombramiento del juez, la inamovilidad en su puesto y el derecho a una carrera-traslados voluntarios, ascensos, jubilación, etc.- a medida que se acumulan sobre él años, canas, lecturas de textos abstrusos y amarguras; de otro, su exclusiva vinculación a la ley y, en su caso, a la jurisprudencia de los tribunales, así como su carácter ajeno a los intereses de las partes sometidas a sus decisiones (imparcialidad).

Dicho de otro modo: el ingreso en la profesión judicial, el ejercicio en condiciones seguras de su trabajo, libre de intereses y de vinculaciones jerárquicas (ningún superior puede transmitirle instrucciones). A su vez, ese juez es o constituye por si mismo un poder, el judicial, que ha de ser respetado por los poderes legislativo $y$ ejecutivo, con los que ha de mantener relaciones ordenadas concertadas- $y$ presididas por el mutuo equilibrio." 14

Conviene, por último, retener un hecho esencial que en muchas ocasiones suele pasar desapercibido, y que tendrá honda relevancia en el constitucionalismo español: la distinción entre poder judicial y Administración de justicia. Un resumen muy didáctico de tal dualidad la ofrece Alejandro Nieto:

"En los paises de cultura occidental democrática, la justicia se articula en dos vertientes complementarias, interactuantes e inseparables: el servicio público de la Administración de justicia, que se presta a los ciudadanos, y el poder judicial, que es la superestructura constitucional que garantiza el equilibrio de las tensiones que inevitablemente surgen en el interior del Estado y cuyo signo más emblemático es el de la independencia tanto de los jueces como del propio poder."15

\subsection{La proyección del contexto politico social en la independencia judicial.}

Como bien indica el juez Stephen Breyer en uno de sus libros: "Words on paper, however, no matter how wise, are not sufficient to preserve a nation", por lo

13 El fundamento jurídico cuarto Sentencia 39/2012 de 19 de marzo del Pleno del Tribunal Constitucional, de forma harto sorprendente ha efectuado una extensión del tal principio. Abordando la independencia del juez ad intra, engloba dentro de la independencia judicial que los jueces puedan apartarse del criterio mantenido por órganos jerárquicamente superiores, sin otra exigencia que motivar las circunstancias que le llevan a apartarse de dicho criterio. Tal doctrina, dicho sea con todos los respetos, me parece disparatada, pues "la idea de salvaguardar la unidad de jurisprudencia no supone violación de la independencia del juez"; José Eugenio SORIANO GARCÍA, El poder, la Administración y los jueces (a propósito de los nombramientos por el Consejo General del Poder Judicial), Iustel, 2012, p. 55. Además, a contrario sensu, lo que viene a sostener, sin tener la gallardia de decirlo explícitamente, es que los países donde se aplica el stare decisis, como Gran Bretaña o Estados Unidos, no existe independencia judicial, ridícula afirmación que no sólo causaría sonrojo, sino auténtica hilaridad. Con ser todo ello sumamente grave, lo peligroso es que el Tribunal Constitucional sacrifica, en aras de una mal entendida independencia judicial, otro valor o principio constitucional, cual es el de la seguridad jurídica.

14 Francisco SOSA WAGNER, La independencia del juez ¿una fábula?, op. cit., p. 28-29

15 Alejandro NIETO, Testimonios de un jurista (1930-2017), op. cit., p. 197-198. 
que se pregunta, a continuacion "what would enable the Constitution to work not only in theory, but also in practice? How could the nation make sure that the Constitution's limits are respected, that our citizens enjoy its important protection, that ur legal system resolves disputes, fairly and impartially, and that our courts dispense justice?"16 La respuesta, según el Breyer, la ofrecen la historia y el entorno social. En similares términos, Diego Íñiguez Hernández indica que: "La evolución de cada modelo obedece a diferencias históricas y de cultura politica, dificilmente trasplantables o reproducibles, que han determinado la articulación efectiva de sus respectivos actores politicos: los tres poderes constitucionales, los demás sujetos institucionales y los medios de comunicación..."17

Y, en efecto, aunque a lo largo de la historia estadounidense han existido ejemplos en los cuales determinadas autoridades han intentado ignorar pronunciamientos judiciales adversos o contrarios a sus intereses ${ }^{18}$, tales comportamientos son excepcionales y, hoy en día, es prácticamente inconcebible en los Estados Unidos que tanto las autoridades como el pueblo desobedezcan abiertamente una resolución judicial ${ }^{19}$, por muy criticable que sea o por muy en desacuerdo que se esté con la misma o con sus razonamientos. Sin embargo, en España no hace falta remontarse a tiempos lejanos para encontrar casos de autoridades públicas que, en el ejercicio de su cargo, han manifestado públicamente $\mathrm{y}$ sin disimulo su intención de no acatar resoluciones que estimasen contrarias a sus intereses.

Para saber quiénes somos, hemos de conocer de dónde venimos, pues, como ocurre en tantas ocasiones, de aquellos polvos vienen estos lodos. De ahí que sea conveniente efectuar un breve recorrido por la evolución del tratamiento del tercero de los poderes a lo largo de nuestro constitucionalismo histórico, para verificar cómo trató de garantizarse la independencia del poder judicial en los distintos textos constitucionales, así como el grado de éxito de las tentativas. Una

16 Stephen BREYER, Making our democracy work. A judge's view, Alfred A. Knoppf, 2010 , p. XII. Para dicho autor, "The Constitution's effort to ensure a workable constitutional democracy mean Little if the public freely ignores the interpretation of the Constitution that dislikes."

17 Diego ÍÑIGUEZ HERNÁNDEZ, El fracaso del autogobierno judicial, op. cit., p. 89.

18 En su obra, Stephen Breyer nos ofrece cuatro ejemplos, de los cuales destaco por su importancia dos, en los cuales el gobierno federal actuó de forma distinta. En el primero, el presidente Andrew Jackson rehusó hacer cumplir las resoluciones judiciales del Tribunal Supremo en el conflicto que mantuvieron el estado de Georgia con la nación cherokee, aunque con posterioridad cambió su postura al comprobar que la situación podía volverse en su contra. El segundo, el asunto de "los nueve de Little Rock", donde ante la negativa del gobernador de Arkansas de llevar a efecto la sentencia Brown v. Board of Education (presionado por la mayoria de los ciudadanos del estado, contrarios a la integración), el presidente Eisenhower envió a la guardia nacional al estado, haciendo cumplir la sentencia con tropas federales que, a bayoneta calada, escoltaron a estudiantes de color hasta el instituto.

19 Quizá nada ilustre mejor este principio que el caso extremo que nos ofrece la polémica sentencia Bush v. Gore. Stephen Breyer, uno de los magistrados discrepantes, manifiesta que: "Whether the decision was right or wrong is not the point here. If I and three other members of the Court thoutht the decision was very wrong, so did millions of other Americans. Fort he present purposes, however, what is important is what happened next. Gore, the losing candidate, told his followers not to attack the legitimacy of the Court's decision. And despite the great importase of the decision, the strong disafreement about its merits, and the strong feelings about the Court's intervention, the public, Democrats as well as Republicans, followed de decision. They did so peacefully, with no need for tropos as in Little Rock, without hurled in the Street, without a violent massive protests"; Making our democracy work, op. cit., p. 70 
historia que, ya adelantamos sin intención de ofrecer spoiler alguno al potencial lector de este trabajo, no tiene ni un desarrollo ni un final feliz.

No pretenden estas páginas efectuar un tratamiento exhaustivo de la materia, sino un mero esbozo de la situación histórica que culminó en el actual Título VI de la Constitución en general y de su artículo 122 en particular.

Hora es ya, pues, de verificar cómo, a lo largo de nuestra historia constitucional, se ha tratado de dotar a la magistratura de esas garantias precisas y necesarias para que la independencia judicial despliegue toda su efectividad.

\section{II.- REGULACIÓN CONSTITUCIONAL DE LA INDEPENDENCIA JUDICIAL DURANTE EL SIGLO XIX20.}

A la hora de adentrarnos en la historia constitucional española del siglo XIX, menester es partir de la atinadísima observación efectuada por Joaquín Varela Suanzes-Carpegna:

"debe establecerse una primera e importantísima distinción: la que separa a la Constitución de 1812 de todas las demás o, dicho de otro modo, al modelo constitucional doceañista del modelo constitucional vigente en España desde 1834 a 1923. A partir de aquí, y sólo a partir de aquí, resulta oportuno distinguir entre el submodelo progresista, que se plasma en la Constitución de 1837 y con más nitidez en la de 1869, y el submodelo liberal-conservador, que cristaliza en el Estatuto Real de 1834 y con más claridad en las Constituciones de 1845 y 1876, las de más larga vigencia en la pasada centuria" 21

Nos encontramos, por tanto, ante dos modelos constitucionales distintos. El primero, representado por el texto constitucional gaditano, responde a unos principios que a la hora de reflejarse en la Constitución se articulan en base a una interpretación muy concreta y particular que le aparta de los restantes documentos constitucionales aprobados a lo largo de la centuria. El segundo, aun respondiendo a los mismos principios básicos (rechazo del absolutismo y de la soberanía del monarca, aceptación plena del principio de división de poderes) ya se caracteriza por una interpretación mucho menos rígida de los principios, más acordes con la evolución doctrinal del liberalismo español, que en este punto se limitó a recoger la propia evolución del liberalismo europeo ${ }^{22}$. Este último

\footnotetext{
20 Para una visión global sobre la materia, con los principales textos normativos sobre el particular, véase Marta LORENTE SARIÑENA, Fernando MARTÍNEZ PÉREZ y María Julia SOLLA SASTRE, Historia legal de la Justicia en España (1810-1978), Iustel, 2012. Sobre la posición de la judicatura en el seno del Estado, puede consultarse también la obra de Miguel Ángel APARICIO, El status del Poder Judicial en el constitucionalismo español (1808-1936), Publicaciones Universidad de Barcelona, 1995.
}

21 Joaquín VARELA SUANZES-CARPEGNA, La Construcción del Estado en la España del siglo XIX. Una perspectiva constitucional, trabajo incluido en el libro Política y Constitución en España, segunda edición, CEPC, 2014, p. 6

22 Sobre la evolución del liberalismo europeo, son de lectura obligada dos trabajos de Joaquín VARELA SUANZES-CARPEGNA. El primero, titulado El liberalismo francés después de Napoleón (de la anglofobia a la anglofilia), publicado en el número 76 de la Revista de Estudios Politicos, p. 29-44; el segundo, apareció en las páginas 63-90 del número 88 de la misma revista, con el título El pensamiento constitucional español en el exilio: el abandono del modelo doceañista (1823-1833). No obstante, el profesor Varela ha revisado profundamente el segundo de los trabajos, 
modelo, que inspira el resto del constitucionalismo decimonónico (prolongado artificialmente hasta 1931) admite dos submodelos, el progresista y el liberalconservador; ambos coinciden en asumir la independencia judicial como uno de los postulados claves de la organización institucional del Estado, aunque el segundo se sienta más cómodo hablando de "Administración de justicia" en lugar de "poder judicial".

Avanzando un paso más, y en lo que a la organización judicial se refiere, para Alejandro Nieto:

"La historia de los modelos judiciales españoles a partir del siglo XIX es sencilla: un modelo constitucional liberal iniciado en las Constituciones de Bayona (1808) y Cádiz (1812) que se conservó ininterrumpidamente hasta 1978, y la posterior incidencia del modelo llamado democrático introducido en los años inmediatamente siguientes, pero que no ha desplazado de manera oficial al anterior, sino que convive con él'23

Diego Íñiguez Hernández apunta el rasgo característico de la historia constitucional española en lo que a la regulación de la independencia judicial se refiere:

"La historia judicial española a lo largo del siglo XIX muestra una sucesión de purgas y cesantías ideológicas, en la que cada cambio politico trajo nombramientos, en ocasiones masivos, de jueces afines y la cesantia de los establecidos por el régimen anterior. Sólo a partir de 1870 se estabilizó relativamente el sistema y se consolidó un sistema de acceso objetivo basado en las oposiciones. La guerra civil y el franquismo trajeron una nueva purga que Toharia ha cifrado en torno al cinco por ciento. Tampoco tuvo vigencia real el principio de separación de poderes: proclamado como instrumento para asegurar la independencia del poder judicial, tuvo en este periodo más de representación mítica o ilusión histórica que de realidad. La independencia quedó asi reducida a una condición personal de cada juez, a una virtud"24.

\subsection{La independencia judicial en los origenes del constitucionalismo.}

Nuestro constitucionalismo vio la luz en una peculiar y dificil coyuntura, en el seno de un conflicto bélico y con el territorio nacional invadido por el ejército francés. Fueron precisamente la invasión napoleónica y la imposición de un monarca extranjero los hechos que curiosamente provocaron en nuestro país el abrupto colapso del Antiguo Régimen, sobre todo debido a la inacción de las instituciones clásicas del mismo, como el Consejo de Castilla, que en tan delicada situación limitaron su actividad a simples protestas ${ }^{25}$.

integrándolo como capítulo sexto en su más reciente libro La monarquía doceañista (1810-1837), Marcial Pons, 2013, p. 319-372.

23 Alejandro NIETO, Testimonio de un jurista (1930-2017), op. cit., p. 189.

24 Diego ÍNIIGUEZ HERNÁNDEZ, El fracaso del autogobierno judicial, op. cit., p. 145.

25 Véase a este respecto la introducción de Carlos Seco Serrano a la obra de Miguel ARTOLA, La España de Fernando VII, Espasa, 1999, p. 15. Dicha obra no es más que una edición como libro independiente del magno estudio que Artola dedicó a dicho monarca en la Historia de España dirigida por Ramón Menéndez Pidal. 
Difícil es, por tanto, que la independencia judicial pudiese surgir ni brillar en tan dificiles circunstancias, lo cual no fue óbice para que los dos textos constitucionales que surgieron en dichos momentos plasmaran en su contenido dicho principio esencial.

\subsubsection{La Constitución de Bayona.}

El texto constitucional de Bayona, tan orillado por nuestra historia constitucional hasta fechas muy recientes ${ }^{26}$, no fue otra cosa que el injerto en nuestro país de los principios napoleónicos coetáneos en la Francia imperial, si bien tamizados inteligentemente con una capa de barniz patrio con la finalidad de que tuviese una acogida favorable. Dicho texto fue defendido y sustentado fundamentalmente por quienes profesaban la ideología afrancesada ${ }^{27}$.

La Constitución de Bayona hacía del monarca el auténtico "nervio del Estado", en consonancia con el modelo napoleónico del que bebía, y por tanto la voluntad regia era incluso superior a la de las propias Cortes ${ }^{28}$. No deja de ser significativo que, tras el primer artículo dedicado a la religión (breve precepto que integraba por sí mismo el título primero), los títulos iniciales del texto estuviesen dedicados al monarca y al poder ejecutivo.

Hay que esperar al Título XI, que, bajo la rúbrica "del orden judicial", aborda la regulación de dicho poder. El mismo reconocía de forma explícita el principio de independencia judicial (artículo 97), pero sin embargo, la justicia se administraba "en nombre del rey" (artículo 98), quien tenía constitucionalmente reconocida la facultad de nombrar a los integrantes de dicho poder (artículo 99). No sólo se constitucionalizaba el nombramiento regio de los jueces, para lo cual el monarca gozaba de la más amplia discrecionalidad sin que su voluntad estuviese mediatizada por órgano o trámite procedimental alguno, sino que incluso se recogía la posibilidad de que los jueces fuesen cesados por el monarca, si bien en este caso respetando unas mínimas formalidades, por cuanto el artículo 100 establecía que ello tan sólo podría llevarse a cabo: "a consecuencia de denuncia hecha por el presidente o el procurador general del Consejo Real, y deliberación motivada del mismo consejo, sujeta a la aprobación del Rey." Como bien indica el profesor Fernández Sarasola, "la independencia mal podia realizarse cuando el Rey tenía reservado el nombramiento y destitución de los jueces."29

26 Acerca del estatuto de Bayona, el mejor estudio sobre dicho texto es el debido a Ignacio FERNÁNDEZ SARASOLA, Una Constitución para España: el Estatuto de Bayona, un extenso estudio introductorio al propio texto constitucional en la magnífica edición de La Constitución de Bayona (1808), tomo I de la colección Las Constituciones Españolas dirigida por Miguel Artola y publicada por Iustel.

27 Sobre la ideología y el fenómeno del afrancesamiento, continúa siendo imprescindible el clásico estudio de Miguel ARTOLA, Los afrancesados, cuya última edición es la de Alianza, 2008, coincidiendo con el bicentenario del inicio de la guerra de la independencia.

28 Ignacio FERNÁNDEZ SARASOLA, Una Constitución para España: el Estatuto de Bayona, op. cit., p. 58-59.

29 Ignacio FERNÁNDEZ SARASOLA, Una Constitución para España: el Estatuto de Bayona, op. cit., p. 90. 
Por tanto, podemos concluir que aun cuando se explicitaba en el propio texto la independencia judicial, el mismo contemplaba igualmente la facultad del monarca de cesar a los jueces. Algo no muy acorde con el principio que se pretendia garantizar, pero que curiosamente se prolongará durante casi toda la centuria.

\subsubsection{La Constitución de Cádiz.}

La Constitución de Cádiz puede considerarse, siguiendo la expresión de Joaquín Varela Suanzes-Carpegna, como la "réplica patriótica" al Estatuto de Bayona. ${ }^{30}$ Uno de los principios nucleares del texto constitucional es precisamente el de división de poderes, y si bien el principio de independencia judicial no está formulado de forma explícita, sí que varios preceptos diseminados a lo largo del mismo respondian a dicha idea básica.

Así, en el Capítulo Primero del Título Quinto, el artículo 243 disponía que " $N i$ las Cortes ni el Rey podrán ejercer en ningún caso funciones judiciales, avocar causas pendientes ni mandar abrir los juicios fenecidos", mientras que el artículo 257 recogía, al igual que lo hiciera el texto de Bayona, que "la justicia se administrará en nombre del Rey, y las ejecutorias y provisiones de los Tribunales superiores se encabezarán también en su nombre." Se trataba de consagrar una independencia judicial que "si bien se sostenía fundamentalmente frente al rey $y$ sus agentes, se afirmaba también con vigor frente a las Cortes."31

La diferencia principal que separaba la Constitución de Bayona y la de Cádiz en esta materia era la extensión de las prerrogativas regias en cuanto a la designación de jueces. Si en aquél el monarca tenía una absoluta discrecionalidad en el nombramiento, los artículos 171 apartado cuarto y 237 del texto gaditano le otorgaban la misma competencia, pero con el decisivo aditamento que ello debería hacerse "a propuesta del Consejo de Estado", órgano consultivo cuyos miembros correspondía nombrar al propio monarca, si bien " $a$ propuesta de las Cortes", como disponía el artículo 233. Quiere ello decir, que en este caso, la voluntad regia quedaba mediatizada por la de las Cortes, dado que eran éstas quienes proponían a los integrantes del órgano consultivo quienes, a su vez, eran los encargados de elevar al monarca las propuestas de designación de jueces. Algo coherente con la desconfianza o recelo con que se contemplaba al monarca, y dado el objetivo último de los constituyentes de situar a las Cortes en el centro de la vida política y constitucional.

También se recogía el principio de inamovilidad de los jueces, que "no podrán ser depuestos de sus destinos, sean temporales o perpetuos, sino por causa legalmente probada y sentenciada, ni suspendidos, sino por acusación legalmente intentada", según disponía el artículo 252. No obstante, el artículo siguiente otorgaba al monarca la facultad de suspender a los jueces en el supuesto de que

\footnotetext{
30 Al profesor Joaquín Varela Suanzes-Carpegna se deben los dos estudios de lectura obligada para comprender los principios jurídicos sobre los cuales se articuló el texto gaditano así como el impacto del mismo en el mundo hispánico: Teoría del Estado en los orígenes del constitucionalismo hispánico (Las Cortes de Cádiz), Centro de Estudios Politicos y Constitucionales, 1983 (hay una reedición publicada en el año 2012 con motivo del bicentenario del texto gaditano) y La monarquía doceañista (1810-1837), Marcial Pons, 2013.
}

31 Joaquín VARELA SUANZES-CARPEGNA, La monarquía doceañista, op. cit., p. 131. 
le "llegaren quejas" contra algún magistrado, si bien se imponían dos requisitos formales inexcusables: formación de expediente en el seno del cual deberían parecer fundadas las quejas y dictamen previo, preceptivo pero no vinculante, del Consejo de Estado; y una vez ejercitada la facultad regia de suspensión, debería remitirse "inmediatamente" el expediente al Tribunal Supremo para que enjuiciase el asunto. En otras palabras, el monarca únicamente gozaba de la facultad de suspender cautelarmente a un juez al incoarse un expediente disciplinario, pero la resolución última de éste correspondería al máximo órgano judicial.

En definitiva, la Constitución de 1812 consagra el principio de independencia judicial, y si bien mantiene la prerrogativa regia de nombramiento de los jueces, mediatiza su ejercicio al disponer que el mismo ha de efectuarse de acuerdo con la propuesta del Consejo de Estado, órgano que a su vez era designado, en la práctica, por las Cortes.

El modelo gaditano no tuvo una enorme fortuna. Tras la desdichada experiencia del trienio constitucional, cuando el Antiguo Régimen feneció definitivamente junto con Fernando VII en septiembre de 1833, el rumbo del constitucionalismo español había virado sobremanera, al igual que lo hiciera el europeo, que pasó de los rígidos esquemas de la separación de poderes característicos de finales del siglo XVIII a un sistema de división de poderes mucho más dulcificado a comienzos del siglo XIX ${ }^{32}$.

\subsection{Constitucionalismo y poder judicial en la era isabelina.}

A lo largo de la era isabelina, la nota característica es la discordancia o separación entre el reconocimiento de la independencia del poder judicial en los textos constitucionales, por un lado, y su paralela inobservancia en la práctica cotidiana debido a las continuas injerencias, fundamentalmente del poder ejecutivo, por otro. Se produce así, por utilizar la célebre metáfora orteguiana, un divorcio entre la situación "oficial" y la "real". Como bien indica en este sentido Diego Íñiguez Hernández: "la realidad del Liberalismo decimonónico muestra una constante incoherencia entre los principios proclamados y la realidad de sus estructuras orgánicas, sus normas de desarrollo constitucional y la aplicación práctica de unas y otras"33.

\subsubsection{Independencia del poder judicial en los textos constitucionales.}

Si prescindimos del fugaz restablecimiento de la Constitución de 1812 tras la vergonzosa sargentada de La Granja en el verano de 1836, son tres los textos constitucionales que se promulgaron en esta época: el Estatuto Real de 1834 y las Constituciones de 1837 y 1845 . En todas ellas, como veremos, no se recoge el principio de independencia judicial stricto sensu, pero sí el de inamovilidad de los jueces.

32 Joaquín VARELA SUANZES-CARPEGNA, El liberalismo francés después de Napoleón: de la anglofobia a la anglofilia, Revista de Estudios Politicos (Nueva Época), número 76 (abril-junio 1992), p. 29-43; del mismo autor, La monarquía doceañista, op. cit., p. 319-372.

33 Diego ÍNIIGUEZ HERNÁNDEZ, El fracaso del autogobierno judicial, op. cit., p. 148. 
El Estatuto Real plantea, en primer lugar, serias dudas en cuanto a su naturaleza, pues se trata más de una carta otorgada que de un texto constitucional propiamente dicho ${ }^{34}$. Pero, en segundo lugar, se trata más que nada de una convocatoria de Cortes, y de una regulación de las cámaras legislativas (que eran designadas con las vetustas denominaciones de Estamento de Próceres y de Procuradores) así como las relaciones entre ambas, articulado todo ello sobre la base de la primacía absoluta del monarca, de cuya voluntad emana el propio texto. Por tanto, no aborda ni menciona, si quiera sea tangencialmente, al poder judicial.

El Estatuto Real no satisfizo a nadie, de ahí el fracaso del sistema, demasiado arcaico incluso para los tiempos en los que fue promulgado. Quizá lo que ocasionó definitivamente su caída fue el no haber logrado su objetivo último, cual era tender un puente al carlismo en armas para que abandonase la lucha, ofreciéndole un sistema en el que pudiera sentirse cómodo y cesar la guerra civil iniciada en $1833^{35}$. Era lógico pues, que si el carlismo rehusaba aceptar la mano que generosamente se le tendia, el Estatuto perdiese de forma inmediata su razón de ser.

Aun cuando el motín de los sargentos en La Granja, debidamente estimulados por las generosas dádivas recibidas al efecto, logró el restablecimiento de la Constitución de 1812 (que se veía aún como un símbolo de la lucha frente al invasor francés pese a la penosa experiencia del Trienio y el nuevo rumbo del liberalismo europeo), pronto se aborda una reforma de la misma, siendo el resultado último la Constitución de 1837 . De esta forma, si el Estatuto Real habia sido una oferta del grueso del liberalismo hacia sus rivales carlistas para reconducirlos hacia la paz, la Constitución de 1837 fue un texto transaccional entre moderados y progresistas, pacto que tanto la guerra carlista como las presiones internacionales contribuyeron a soldar ${ }^{36}$.

El Poder judicial se regula en el Título $X$, $y$ si bien no se recoge de forma explícita el principio de independencia judicial, sí que se contienen dos manifestaciones al respecto. El artículo 63 establece que " $a$ los Tribunales $y$ Juzgados pertenece exclusivamente la potestad de aplicar las leyes en los juicios civiles y criminales, sin que puedan ejercer otras funciones que las de juzgar $y$ hacer que se ejecute lo juzgado." Pero, sobre todo, el artículo 66, que constitucionaliza la inamovilidad del juez: "Ningún magistrado o juez podrá ser depuesto de su destino, temporal o perpetuo, sino por sentencia ejecutoria, ni suspendido sino por auto judicial, o en virtud de orden del Rey cuando éste, con motivos fundados, le mande juzgar por el Tribunal competente." La Justicia, según el artículo 68, "se administra en nombre del rey."

34 Véase la introducción de Juan Pro Ruiz a la edición del Estatuto Real que obra en el tercer volumen de Las Constituciones Españolas editadas por Iustel, 2010. Como indica dicho autor, pese a datar de 1968 continúa siendo de lectura obligada el estudio de Joaquín TOMÁS VILLARROLLA, El sistema politico del Estatuto Real, Instituto de Estudios Políticos, 1968.

35 Carlos SECO SERRANO, Historia del conservadurismo español, Temas de Hoy, 2000.

36 Joaquín VARELA SUANZES-CARPEGNA, La Constitución española de 1837: una constitución transaccional, incluido en su libro Politica y Constitución en España (1808-1978), segunda edición, Centro de Estudios Políticos y Constitucionales, 2014, p. 373-386. 
En 1843 una alianza coyuntural entre progresistas y moderados acabó con la regencia de Espartero, pero tras ese logro, el pacto se quebró, y los moderados lograron, siquiera temporalmente, sumir al progresismo en una crisis de primera magnitud tras el affaire Olózaga, a quien se acusó de forzar a la reina para obtener el decreto de disolución de las Cortes ${ }^{37}$. Una vez en el poder, los moderados impulsaron una reforma ${ }^{38}$ que imprimiese al texto constitucional de 1837 un tamiz mucho más conservador, en lógica coherencia con la doctrina de la constitución histórica ${ }^{39}$. En lo que al Poder Judicial se refiere, el Título X no sufre mutación alguna más que en la rúbrica, (aunque la misma es ciertamente decisiva en su alcance, pues se degrada el "poder judicial" a una simple "Administración de Justicia") y en la numeración de los artículos, que en cuanto a su contenido material reproducen literalmente los del texto de 1837.

Desalojados los moderados del poder en 1854 al triunfar la Vicalvarada, durante el bienio progresista se abordó una modificación constitucional que, en lo que a estos efectos interesa, mantenía incólume la redacción de sus predecesoras. El judicial recuperaba la condición de "poder", y en el articulado no se introducía más que un leve añadido al precepto relativo a la imposibilidad de deponer al juez, artículo al que se añadía el siguiente párrafo: "Las bases de la ley orgánica de tribunales determinarán los casos y la forma en que gubernativa $y$ disciplinariamente podrán los magistrados $y$ jueces ser trasladados, jubilados $y$ declarados cesantes." Remisión, pues, al desarrollo legislativo del precepto constitucional.

Visto el apretado resumen, podemos concluir que en lo que al tratamiento constitucional se refiere, si algo puede predicarse de la regulación del poder judicial es la estabilidad normativa, por cuanto pese a la existencia de dos textos constitucionales (los de 1837 y 1845) y un proyecto (1856), el contenido material de la regulación del tercer poder se mantiene incólume desde 1837. Y las dos notas características de esa regulación son: primero, la garantía de que la potestad de juzgar y hacer ejecutar lo juzgado se atribuye en exclusiva al poder judicial; segundo, que los jueces únicamente pueden ser depuestos por sentencia judicial, si bien se mantiene la potestad del rey para suspender cautelarmente al juez de sus funciones, si bien únicamente en supuestos que concurriesen "motivos fundados"; y tercero, la propia condición de "poder" judicial, que los liberales terminológicamente respetaban, pero que disgustaba a los conservadores, mucho más cómodos con una simple “Administración” de justicia.

37 Sin duda alguna el mejor análisis histórico sobre este curioso e interesante episodio es el debido a Alejandro NIETO GARCÍA, Los “sucesos de palacio" del 28 de noviembre de 1843, Real Academia de Ciencias Morales y Politicas, 2007.

38 Juan Ignacio MARCUELLO BENEDICTO, El proceso de formación de la Constitución de 1845 y su caracterización, estudio preliminar a la edición de La Constitución de 1845, cuarto volumen de Las Constituciones Españolas editadas por Iustel, 2007.

39 Joaquín VARELA SUANZES-CARPEGNA, La doctrina de la constitución histórica de España, incluido en su libro Politica y Constitución en España (1808-1978), segunda edición, Centro de Estudios Políticos y Constitucionales, 2014, p. 115-159. 


\subsubsection{La realidad: injerencia del ejecutivo en el poder judicial.}

Como cualquier jurista práctico sabe perfectamente, una cosa es la regulación normativa y otra muy distinta su aplicación práctica; es decir, siguiendo la afortunada expresión de Alejandro Nieto, la dicotomía entre derecho normado y derecho practicado.

Pese a que a nivel constitucional hemos visto que lo que caracterizó el periodo isabelino fue la estabilidad material pese a las sucesivas mutaciones constitucionales, en la realidad lo que primó fue la injerencia más absoluta y descarnada del poder ejecutivo en el judicial, hecho éste que destacan todos los autores que han abordado el tema ${ }^{40}$. No es ya que fueran constantes las intromisiones del gobierno en la judicatura, sino que incluso los principales autores negaban al poder judicial la autonomía o sustantividad propia.

Valgan tres ejemplos altamente significativos.

El primero, nos lo ofrece la Memoria que en 1837 redacta nada menos que el Ministro de Justicia, Pablo Mata Gil, y en el que se refiere en la práctica a la inamovilidad judicial consagrada en la Constitución aprobada ese mismo año en los siguientes términos:

"no se quiso que aquella disposición constitucional tuviera cumplido efecto desde el instante de su publicación sino que se la dejó sometida y dependiente de la ley orgánica que establezca las cualidades de que deben estar adornados los Magistrados y Jueces y el modo y forma de proceder para su nombramiento, De aqui es que la Corona ha ejercido libremente y sin contradicción desde el restablecimiento del Gobierno representativo el derecho de separar, trasladar $y$ jubilar a los Magistrados y Jueces, usando de él con más o menos parsimonia, con más o menos latitud (...) Nadie conoce mejor que el Gobierno ni nadie tampoco puede estar más convencido que él de la necesidad de cesar lo más pronto posible el estado de ansiedad y zozobra en que están constituidos los Magistrados y Jueces (...) mas a nadie es tampoco dado a conocer mejor que al mismo Gobierno las graves consecuencias que puede producir, aun para la misma magistratura, la inoportuna o ciega aplicación de aquel principio en las críticas y espinosas circunstancias en que la Nación se encuentra."41

En definitiva, que el propio titular de Justicia reconocía en primer lugar, que el principio de inamovilidad consagrado en la Constitución no era de aplicación directa, quedando su eficacia demorada al desarrollo legislativo; y en segundo, lugar que el Gobierno había utilizado sus prerrogativas para meter mano en la judicatura trasladando, cesando o jubilando. Y nótese que aun cuando justifica la preocupación de la magistratura por la incertidumbre en el desempeño de sus funciones, va más allá al decir que la aplicación de dicho principio puede resultar perjudicial en la situación del momento, es decir, en plena guerra carlista.

40 Es al respecto muy ilustrativa la lectura del trabajo de Braulio DÍAZ SAMPEDRO, La politización de la Justicia: El Tribunal Supremo (1836-1881), Facultad de Derecho de la Universidad Complutense de Madrid, 2004; se trata de la memoria presentada por el autor para optar al grado de Doctor en Derecho, si bien ulteriormente publicó una versión de dicha memoria en forma de libro con el título La politización de la Justicia, Dikynson, Madrid, 2005. Véase, igualmente Diego ÍNIGUEZ HERNÁNDEZ, El fracaso del autogobierno judicial, op. cit., p. 149-150.

41 Citado en Miguel Ángel APARICIO, El status del poder judicial en el constitucionalismo español (1808-1936), op. cit., p. 56. 
El segundo de los ejemplos nos sitúa ocho años más tarde, en el año 1845, cuando se debate en las Cortes españolas el sistema de control de la Administración pública, uno de los aspectos más decisivos y relevantes, por cuanto supone para el ciudadano nada menos que la defensa frente a los actos de poder público. Pues bien, cuando se aborda la opción entre un sistema judicialista de tipo anglosajón o un sistema administrativo de corte francés, los autores explicitan de la forma más descarnada el hecho de que no reconocen al poder judicial como independiente, sino que lo engloban directamente en el seno del poder ejecutivo. En este punto, Alejandro Nieto expone la situación en los siguientes términos:

"En Francia, medio siglo antes se habia partido de las mismas bases, y en la alternativa entre el Poder ejecutivo y el Poder judicial (al margen, naturalmente, del Poder legislativo), se decidieron por el Poder ejecutivo, con objeto de que el Poder judicial no perturbase sus actividades. En España, sin embargo, la situación constitucional es en 1845 muy distinta, y por ello no surge la citada alternativa. Nuestros autores no reconocen el Poder judicial, autonomía constitucional, sino que le consideran como parte integrante - junto al Poder administrativo- del Poder ejecutivo, que corresponde al Monarca. El problema constitucional queda asi modificado, y va a tratarse solamente de una simple decisión del Monarca, inspirada en razones de pura oportunidad.

Corresponde aqui, primero, demostrar con los textos la afirmación que acaba de hacerse. "El Gobierno de toda la nación —dice Gil de Zárate en el lugar citadose divide, como es sabido, en dos grandes ramas: el Poder legislativo y el Poder ejecutivo..., lo que regularmente se llama el Poder judicial no es más que uno de los ramales del Poder ejecutivo, una emanación suya, cuyo objeto es aplicar las Leyes que arreglan los intereses de los particulares entre sí." $Y$ al año siguiente (1839) se publican las siguientes palabras de Silvela: "El supremo administrador del Estado debe ser, al propio tiempo, el Juez supremo de las contiendas administrativas, bajo la responsabilidad de sus Ministros. A la verdad, este principio no se halla explicito en nuestra Ley fundamental, como no lo está en ninguna constitución; mas no por eso deja de estar virtualmente comprendido en todas ellas... Además, de tiempo inmemorial en España, el Rey está en posesión de ejercer aquel derecho" "42

Pero es que, además, al articularse el procedimiento contenciosoadministrativo mediante las leyes de 2 de abril y 6 de julio de 1845, se consagra, por utilizar una acertada expresión de Enrique Orduña Rebollo, el "blindaje del Poder ejecutivo frente al judicial"43, pues los asuntos más delicados (por ejemplo, la contratación administrativa) van a extraerse de la jurisdicción ordinaria y residenciarse en órganos administrativos, que, en el caso de la Administración

42 Alejandro NIETO, Orígenes de lo contencioso-administrativo en España, Revista de Administración Pública número 50 (mayo-agosto 1966), p. 33. "Ni la independencia, ni la inamovilidad quedaron firmemente establecidos. $Y$ los debates constitucionales muestran una concepción subordinada del poder judicial, que aunque con una cierta independencia funcional teórica- a través de la inamovilidad, emana del ejecutivo"; Diego ÍÑIGUEZ HERNÁNDEZ, El fracaso del autogobierno judicial, op. cit., p. 150.

43 Enrique ORDUÑA REBOLLO, Historia del Estado español, Marcial Pons, 2015, p. 529. 
central, implicaba que "los ministros adquirian la condición de jueces administrativos de excepción", dado el sistema de justicia retenida implantado ${ }^{44}$.

Para el último de los ejemplos, hemos de situarnos ya en 1869, cuando el jurista Pedro Gómez de la Serna afirmó que "el orden judicial es una desmembración del poder ejecutivo [...] no es un verdadero poder, no tiene vida ni acción propia." 45

Sirvan estos tres botones de muestra para exponer en qué se traducía en realidad cotidiana la independencia judicial: en un spoil system puro y duro; en la continua injerencia, incluso en etapas de gobiernos progresistas, del gobierno en la judicatura, que se hacía directamente a través no sólo de los nombramientos, sino de los traslados y ceses, en la inmensa mayoría de los casos por motivos estrictamente politicos. Incluso alguien como Gómez Becerra, adalid de la independencia judicial, defendia la necesidad previa de depurar los elementos desafectos al gobierno y procedentes de épocas anteriores. Y justificaba la necesidad de tal purga nada menos que desde su propio escaño de las Cortes:

"si bien es verdad que los Jueces cuando han sido nombrados conforme a las leyes deben ser inamovibles, lo es también que no puede revestírseles de esta consideración en épocas de cambios politicos, pues si no hubieran sido mudados, aún existirian en sus villas todos los jueces nombrados por Calomarde."46

Por lo tanto, pese a las constantes y reiteradas invocaciones a la sacrosanta independencia judicial, lo cierto es que moderados y progresistas iban de la mano a la hora de sostener que la misma debía aplicarse, efectivamente, pero una vez purgado el estamento judicial de elementos "peligrosos" o "desafectos", que no eran otros que los nombrados o elevados por los ejecutivos anteriores. Ante dicha situación, "resultaria grotesco hablar siquiera de independencia de los jueces, como tampoco puede extrañar su ignorancia y corrupción." 47

\section{III.- DOS INTENTOS PARA GARANTIZAR DE FORMA EFECTIVA LA INDEPENDENCIA JUDICIAL: 1873 Y 1923.}

Si el constitucionalismo español nace en las circunstancias fácticas menos favorables, los dos intentos de garantizar de forma efectiva la independencia judicial ven la luz en una coyuntura histórica no precisamente óptima para lograr dicho objetivo. Analizaremos brevemente esos dos hitos normativos que, si bien tuvieron lugar extramuros de los textos constitucionales, no por ello dejan de merecer la atención por su notable importancia en nuestra historia legislativa.

44 Enrique ORDUÑA REBOLLO, Historia del Estado español, op, cit., p. 530-531. Para un recorrido histórico sobre la jurisdicción contencioso-administrativa, véase Juan Ramón FERNÁNDEZ TORRES, Historia legal de la jurisdicción contencioso-administrativa (1845-1998), Iustel, 2007.

45 Citado en Francisco SOSA WAGNER, La independencia del juez ¿una fábula? op. cit., p. 30.

46 Miguel Ángel APARICIO, El status del poder judicial en el constitucionalismo español (18081836), op. cit., p.65.

47 Diego ÍNIIGUEZ HERNÁNDEZ, El fracaso del autogobierno judicial, op. cit., p. 152. 


\subsection{E1 fugacisimo precedente de 1873.}

\subsubsection{Los hitos normativos del sexenio democrático: Constitución de 1869 y Ley de 15 de septiembre de 1870.}

La Constitución de 1869 regula el poder judicial en su Título VII, que recupera la expresión "poder judicial" perdida tras el restablecimiento del texto constitucional de 1845. Su regulación es algo más extensa, y aun cuando mantiene algunos principios que habían permanecido inalterados a lo largo de medio siglo de constitucionalismo ${ }^{48}$, contiene novedades de calado en lo que a la independencia judicial se refiere. Ello se debió a que, como indica en este punto Manuel Pérez Ledesma, "fue en este Título en el que la Comisión aceptó un mayor número de reformas [...] probablemente el resurgimiento del debate se debió al hecho de que entre los diputados habia un alto número de juristas interesados en la definición constitucional del poder judicial, y en especial en la nueva regulación de la carrera de los jueces, que fue el tema que dio pie a las más intensas discusiones. Lo que se discutia en los articulos referidos a la carrera judicial y a la responsabilidad de los jueces era el mejor modo de mantener la independencia judicial, acabando con las arbitrariedades anteriores." 49

El artículo 94 disponía que el nombramiento de los magistrados y jueces correspondía al rey a propuesta del Consejo de Estado, si bien "con arreglo a la ley orgánica de Tribunales", tras lo cual introducía por vez primera en nuestro constitucionalismo una novedad de hondo calado: "el ingreso en la carrera judicial será por oposición." Se pretendía así, por tanto, racionalizar el ingreso garantizando que los jueces estuviesen capacitados para el ejercicio de sus funciones, algo que hasta ese momento no se había logrado del todo. No obstante, y pese a ese esfuerzo por establecer unos criterios racionales y objetivos para el ingreso, se dejaba una puerta abierta al monarca: "podrá nombrar hasta la cuarta parte de Magistrados de las Audiencias y del Tribunal Supremo sin sujeción a lo dispuesto en el párrafo anterior ni a las reglas generales de la ley orgánica de Tribunales; pero siempre con audiencia del Consejo de Estado y dentro de las categorias que para estos casos establezca la referida ley." 50 Amén de lo anterior, se establecía una especie de control interno de legalidad por los propios órganos jurisdiccionales, en cuanto el artículo 96 disponía que "los Tribunales, bajo su responsabilidad, no darán posesión á los Magistrados o Jueces que no hubieren sido nombrados con arreglo a la Constitución y las leyes."

$48 \mathrm{E} 1$ hecho de que a los Tribunales corresponda exclusivamente la potestad de aplicar las leyes y que la justicia se administre en nombre del Rey (artículo 91). Sin embargo, y a diferencia de otros textos constitucionales, explicitaba la posibilidad de inaplicar normas reglamentarias que contraviniesen lo dispuesto en las leyes (artículo 92) y se generalizaba el juicio por jurado (artículo 93), previsión ésta muy cara al progresismo español del siglo XIX.

49 Manuel PÉREZ LEDESMA, Estudio preliminar a La Constitución de 1869, quinto volumen de Las Constituciones españolas, Iustel, 2010, p. 108

50 Esta posibilidad de nombramiento de jueces sin pasar por una oposición fue "un sistema que a Figueras le pareció que abría la puerta del favoritismo, pero que fue votado por la mayoría de diputados, convencidos por Silvela de la necesidad de un periodo de transición entre un sistema de arbitrariedad y favoritimo y un sistema de absoluto rigor como el que se va a establecer"; Manuel PÉREZ LEDESMA, Estudio preliminar a La Constitución de 1869, op. cit., p. 109. 
Ahora bien, una cuestión era racionalizar el ingreso y otra muy distinta abordar lo que hasta el momento era el auténtico coladero a través del cual el poder ejecutivo introducía sus peligrosas zarpas en la judicatura: las suspensiones, traslados y cesantias. En este punto, se pone fin a una de las tradicionales prerrogativas de la Corona, cual era la facultad de suspensión cautelar de los jueces, dado que el artículo 95 disponía que "podrán ser suspendidos por auto del Tribunal competente", lo que privaba al monarca y a sus ministros ejercer dicha facultad. Dicho precepto establecía que únicamente cabría el traslado o la deposición de un juez por "sentencia ejecutoria o por Real decreto acordado en Consejo de Ministros previa consulta del Consejo de Estado, y al tenor de lo que se disponga en la mencionada ley orgánica."

De todas formas, una atenta lectura del texto constitucional permite verificar que muchos de los preceptos se remitian al desarrollo legislativo, en concreto a la "ley orgánica de Tribunales." Dicha previsión se cumplió con la aprobación de la Ley provisional sobre Organización del Poder Judicial, aprobada el 15 de septiembre de 1870. Quizá por una de esas peculiaridades tan características de la historia española, ese carácter "provisional" permitió al texto normativo gozar de una larga y próspera vida, pues mantuvo su vigencia hasta que fue derogado por la actual Ley Orgánica 1/1985 de 1 de julio, del Poder Judicial; es decir, casi ciento quince años de existencia. Dicha norma intenta poner fin a los nombramientos arbitrarios generalizando el sistema de ingreso por oposición.

\subsubsection{El Decreto Salmerón de 8 de mayo de 1873.}

El viernes 9 de mayo de 1873 se publica en la Gaceta un Decreto aprobado el día anterior y elaborado a instancias de Nicolás Salmerón, Ministro de Gracia y Justicia. El texto contaba con una amplia exposición antepuesta al articulado en la cual se desgranaban tanto los objetivos como los principios inspiradores de la nueva regulación.

La Exposición se caracteriza por su florida retórica, muy propia de la época, y desde sus primeras lineas deja bien claro y manifiesto cuál es el objetivo último, a la vez que se describe de la forma más tétrica, que no menos realista, la situación anterior. La normativa no otra cosa busca más que: "en ningún caso debe restaurarse la antigua involucración del Poder Judicial con el Ejecutivo, de cuya tutela urge por completo emanciparlo, no sólo en el ejercicio de su autoridad, sino también en el nombramiento e investidura de sus representantes", algo que calificaba unas lineas más delante de "perturbador predominio" imputado a una "triste herencia de la institución monárquica." Se trata, en definitiva, de hacer que la ley "se cumpla en lo relativo al nombramiento, ascenso, traslación y separación de los funcionarios del Poder judicial, sin el dañoso arbitrio del Ministro, y deshacer las ilegalidades que en este punto hayan podido cometer las administraciones anteriores."

$\mathrm{Y}$ aun reconociendo los avances que supusieron el texto constitucional de 1869 y la Ley de 13 de septiembre de 1870, considera ambos como insuficientes, el primero por estar "imbuido todavia en los principios que hacian de la Administración de justicia una de las altas prerrogativas de la Corona", y el segundo por su carácter provisional. Provisionalidad que predica curiosamente de la propia regulación que presenta, dado que la aprueba con carácter transitorio "mientras en tan vital asunto deciden las futuras Constituyentes, a qué todos 
debemos fiar la instauración definitiva del libro organismo del Estado, que en la forma republicana tiene la más alta consagración que la razón humana hasta hoy concibe."

Lo que pretendía el Decreto era sustraer del seno del ejecutivo la facultad de cobertura de vacantes, trasladándola al Tribunal Supremo. Así, dicho precepto normativo disponía que todas las vacantes de Jueces, Magistrados y Fiscales (con excepción de Presidente y Fiscal del Tribunal Supremo) habrian de ser objeto de publicación oficial en el plazo de 15 dias. Los funcionarios que deseasen ocupar el puesto vacante deberian elevar las instancias al Ministerio de Gracia y Justicia, pero dicho órgano limitaba sus funciones a la mera recepción de las solicitudes, formar un expediente general para la vacante y elevarlo al Tribunal Supremo, que sería el encargado de formular la propuesta "unipersonal y razonada", para la cobertura de cada vacante a la vista del expediente general, si bien podía solicitar, antes de efectuar la propuesta "si lo estimare conveniente", podría solicitar del Ministerio los expedientes particulares de los candidatos. Trasladada la decisión al indicado departamento ejecutivo, el titular "expedirá los nombramientos, expresando las condiciones especiales en virtud de las que ha obtenido el nombrado el ingreso o ascenso en la carrera."

Se trataba, por tanto, de desplazar las facultades decisorias desde el Ministerio de Gracia y Justicia hacia el Tribunal Supremo. La Exposición del Decreto justificaba mutación tan radical de la siguiente forma: "Amplia confianza pone el Ministro que suscribe en el alto Cuerpo, a quien en primer término compete velar por el honor de la Magistratura española, esperando habrá de cumplir su nuevo cometido con el riguroso celo y severa justicia que corresponde a hombres de honor $y$ de conciencia fortalecidos con el culto del derecho y templados en el servicio a la patria."

La madrugada del dos al tres de enero de 1874 un batallón de guardias penetra en el Congreso y disuelve el mismo, poniendo fin a la no muy dichosa etapa republicana. Apenas dos semanas más tarde, la Gaceta del viernes 16 de enero de 1874 publica un Decreto elaborado dos dias antes por Cristino Martos, Ministro de Gracia y Justicia. Lo curioso de esta norma no radica en su articulado (dos breves preceptos limitados a derogar el Decreto de 8 de mayo de 1873 y a disponer que el Ministro de Justicia reclame del Tribunal Supremo los expedientes en tramitación para ser resueltos) sino en la desproporcionada extensión del preámbulo justificativo que excede con mucho en extensión a la parte normativa. Aun cuando contiene alguna que otra manifestación ciertamente chocante ${ }^{51}$, imputa a la normativa que deroga no sólo vulnerar la Constitución, sino desconocer "principios universalmente reconocidos", y justifica su decisión de regresar al sistema tradicional de la siguiente forma:

"admitiendo el supuesto de que las facultades que tal disposición otorga al Tribunal Supremo sobre nombramiento, ascenso y traslación de funcionarios del Poder judicial debieran corresponderle, todavia surge otra dificultad de carácter práctico, pero cuyas deplorables consecuencias afectan quizá a la Administración de justicia. El Tribunal Supremo tiene una organización adecuada al cometido que

51 Como decir, por ejemplo: "pero suponer una vez subsistente la ley orgánica, siquiera sea con el carácter provisional, que en el nombramiento, ascenso o traslación de los funcionarios del Poder Judicial no impera otro criterio que el de la arbitrariedad es tan aventurado como desprovisto de exactitud." 
según la Constitución de 1869 y la ley orgánica del Poder judicial le atribuyen, y el decreto de 8 de mayo de 1873, sin tener en cuenta esta capital consideración, le confiere graves y penosas atribuciones que de seguro, aunque ejercidas con la rectitud de tan elevado Cuerpo, podrian a la larga ceder en menoscabo de la pronta y cabal administración de justicia."

En definitiva, la decisión última de poner fin al primer intento de autogobierno judicial de nuestra historia se justifica tanto en principios de carácter político-constitucional como de mera eficacia, dado que el tiempo consumido en dichas funciones (que no deja de tener su miga se califiquen de "graves y penosas"), redundaría en perjuicio del correcto ejercicio de las funciones jurisdiccionales.

\subsubsection{E1 Proyecto de Constitución Federal de la República española.}

El Proyecto de Constitución Federal entraña novedades significativas no sólo en cuanto a la organización territorial del Estado, sino en cuanto a la propia organización del Poder Judicial, donde se acusa la influencia del sistema norteamericano, muy admirado en aquel entonces, si bien con ciertos matices que impiden su asimilación total en nuestro país.

No es este el momento de abordar las tesis federalistas sustentadas por entonces, ni el grado de desconocimiento de las mismas entre sus propios defensores, como puso en evidencia José de Echegaray, entonces Ministro de Hacienda, el 8 de marzo de 1873 en las propias Cortes ${ }^{52}$, ni tampoco el impacto que ello tuvo en cuanto a ruptura con el hasta entonces incuestionado centralismo ${ }^{53}$, sino concentrarnos en la articulación del poder judicial en el proyecto de Constitución.

El título X es recoge los preceptos referidos al Poder Judicial. La influencia norteamericana es palpable, por ejemplo, a la hora de configurar al Tribunal Supremo no sólo como órgano encargado de velar por la constitucionalidad de las leyes, facultándole para "suspender los efectos" de una ley "contraria a la Constitución" (artículo 77) ${ }^{54}$, sino como encargado de decidir los litigios entre los estados (artículo 78), los conflictos entre los poderes públicos de un Estado y los

52 Véase al respecto el interesante análisis de Alejandro NIETO, El Federalismo español en 1783, incluido en la obra colectiva Memorial para la reforma del Estado, Estudios en homenaje al profesor Santiago Muñoz Machado, tomo II, CEPC, 2016, p. 1069-1088. No me resisto a dejar de incluir la cita del discurso de Echegaray, transcrita por Nieto: “¿Cuál es la República federal de los hombres de pensamiento [...] Declaro humildemente que no lo sé. Y he consultado con algunos de vosotros. Yo les he pedido su idea, su definición [...] Nosotros hemos pedido a los hombres del partido republicano una, dos y tres veces, una doctrina, un programa y no lo hemos conseguido. ¿Por qué? Yo creo que es porque no existe una idea bien definida, porque no tenéis una República federal, porque no sabéis lo que es vuestra República."

53 En este punto, véase Joaquín VARELA SUANZES-CARPEGNA, La cuestión territorial en las dos repúblicas españolas, incluido también en la obra colectiva Memorial para la reforma del Estado, Estudios en homenaje al profesor Santiago Muñoz Machado, tomo II, op. cit., p. 1089-1109, si bien el análisis de la Primera República stricto sensu se contiene en las diez primeras páginas, abordando las restantes el segundo de los experimentos republicanos.

54 En esto radica la diferencia principal entre el proyecto de 1873 y la realidad estadounidense. En la otra orilla del Atlántico, cualquier órgano judicial (no sólo el Tribunal Supremo) ostentaba la facultad de judicial review, mientras que en nuestro país el proyecto concentraba dichas potestad en el máximo órgano judicial. 
asuntos en que la Nación sea parte (artículo 79). De igual forma, se constitucionaliza el juicio por jurado en toda clase de delitos, se impone la colegialidad de todos los Tribunales y se facultaba al máximo órgano judicial para dictar su "reglamento interior" y nombrar a "todos sus empleados subalternos."

En lo relativo a la independencia judicial, existen varios preceptos que tocan dicho particular. Así, se establecía la "oposición verificada ante las Audiencias de los respectivos Estados" como medio de acceso a la categoría de juez de distrito, mientras que las Audiencias estarian integradas por "jueces de distrito ascendidos a magistrados en concurso público y solemne." Se trata, por tanto, de un sistema caracterizado mediante el ingreso por oposición al nivel inferior (juzgado de distrito) y ulteriormente ascenso por concurso para los niveles superiores (Audiencias). En lo que respecta al Tribunal Supremo federal el artículo 73 disponia que "se compondrá de tres magistrados por cada Estado de la Federación”, sin precisar más. Se pretendió garantizar la independencia de la judicatura garantizando que las facultades de separación de sus integrantes correspondería al propio poder judicial, en cuanto el artículo 75 establecía que los jueces y magistrados "no podrian ser separados sino por sentencia judicial o por acuerdo del Tribunal Superior jerárquico", si bien el artículo 76 admitía una excepción para los magistrados del Tribunal Supremo, que podrian ser "removidos por una comisión compuesta por iguales partes de Representantes del Congreso, del Senado, del Poder Ejecutivo y del mismo Tribunal Supremo."

\subsubsection{E1 regreso al sistema tradicional: la Constitución de 1876.}

El fracaso de la monarquía de Amadeo de Saboya y del experimento republicano, propiciaron una corriente favorable a la entronización del príncipe Alfonso, hijo de la destronada Isabel II, movimiento hábilmente guiado por Antonio Cánovas del Castillo, redactor material del "Manifiesto de Sandhurst", que formalmente aparecia rubricado el 1 de diciembre de 1874 por el futuro monarca. El deseo de Cánovas de un regreso de la monarquía por aclamación popular, se frustró con el pronunciamiento del general Arsenio Martínez Campos en Sagunto el 31 de diciembre de 1874, en el cual se proclama rey de España a don Alfonso XII, dando paso al periodo histórico conocido como "restauración borbónica" que se articularía mediante la Constitución de 1876, texto constitucional que hasta la fecha es el más longevo de nuestra historia, pues regirá hasta el 14 de abril de 1931, si bien mediando el periodo de "suspensión" del mismo durante la dictadura de Primo de Rivera ${ }^{55}$.

En lo que atañe a la regulación del poder judicial, el proyecto de Constitución "se aprobó con un breve debate en el Congreso y sin debate en el Senado" y "reforzaba la subordinación al Gobierno de los jueces y magistrados en lo

55 Un magnífico análisis que, como todos los suyos, liga el proceso constituyente con los hechos históricos en los que se inserta y con las doctrinas constitucionales del momento, es el debido a Joaquín VARELA SUANZES-CARPEGNA, Elaboración y características de la Constitución de 1876, incluido como estudio preliminar a La Constitución de 1876, Tomo VII de la colección Las Constituciones españolas, Iustel, 2009, p. 19-97, trabajo que con posterioridad el autor incluyó en la segunda edición de su libro recopilatorio Politica y Constitución en España (1808-1978), CEPC, 2012, p. 633-705. 
tocante a la selección y ascenso de éstos." 56 En plena coherencia con el ideario liberal-conservador, se mutaba de nuevo la denominación, hablando de "Administración de Justicia" en lugar de "poder judicial". La justicia se administraba "en nombre del rey" (artículo 74) y se consagraba la inamovilidad de los magistrados y jueces, que, se decia, "no podrán ser depuestos, suspendidos ni trasladados, sino en los casos y en la forma que prescriba la ley de los tribunales" (artículo 80). Ello supuso la continuidad legislativa, puesto que permanecía en vigor la Ley de 15 de septiembre de 1870, "aunque se vio afectada por la Ley Adicional de 1882, auspiciada por Alonso Martinez, que, además de algunas novedades en la jurisdicción penal, incrementó la dependencia gubernamental de los jueces, al permitir, por ejemplo, que el ejecutivo seleccionase parte de los miembros de la carrera judicial" 57 . Por tanto, nada nuevo bajo el sol, dado que se recupera la tradición patria de reflejar a nivel constitucional todas las garantías de independencia para jueces y magistrados, degradándola en la práctica debido a las injerencias del ejecutivo en el judicial.

A nivel práctico, la se prolongó la situación anterior. Y así, como indica Orduña Rebollo, "el Poder judicial no experimentó cambios en su situación constitucional, y se consolidó como un aparato burocrático estatal inserto, según Suárez Bilbao, en el conjunto institucional del sistema politico. La continuidad y vigencia de la Ley Orgánica del Poder Judicial de 1870 era una realidad y las revisiones posteriores no introdujeron novedades ni cambios en su estructura funcional." $58 \mathrm{Y}$ el "blindaje" del ejecutivo frente al judicial no sólo se mantuvo, sino que se acentuó. Así, en el debate de la que se convertiría en Ley de 13 de septiembre de 1888, ley Santamaria Paredes, y que consagró un sistema armónico de composición mixta para el conocimiento de los asuntos contenciosoadministrativos:

"se articularon aún una serie de precauciones o 'válvulas de seguridad para 'hacer inofensiva una jurisdicción operando contra el Ejecutivo. Esas expresiones entrecomilladas se oyeron sin recato en el debate ante las Cámaras de la Ley Santamaria, y pronunciadas por hombres cualquier cosa menos ingenuos (Cánovas, Colmeiro, Conde de Torreanaz) y sobre ellas se montaron mecanismos en cadena para esterilizar las ejecutorias judiciales: reserva plena de la ejecución de las Sentencias a las Administraciones demandadas; posibilidad para el Consejo de Ministros de declarar su inejecución por causas virtualmente abiertas y aun, además, la posibilidad de un recurso extraordinario de revisión abierto al Fiscal cuando entendiese que una sentencia firme se hubiese dictado con incompetencia; inembargabilidad total de los caudales públicos, etc."59

\footnotetext{
56 Joaquín VARELA SUANZES-CARPEGNA, Elaboración y características de la Constitución de 1876, op. cit., p. 86.

57 Joaquín VARELA SUANZES-CARPEGNA, Elaboración y características de la Constitución de 1876, op. cit., p. 86-87.

58 Enrique ORDUÑA REBOLLO, Historia del Estado español, op. cit., p. 708.

59 Eduardo GARCÍA DE ENTERRÍA y Tomás Ramón FERNÁNDEZ RODRÍGUEZ, Curso de Derecho Administrativo II, Thomson-Reuters, Pamplona, 2013, p. 586. Por cierto, que muchas de esas "válvulas de seguridad" no tuvieron dificultad en traspasar el umbral de la Constitución de 1978 y permanecen vigentes en la actualidad. Véase Jorge PÉREZ ALONSO, La ineficacia del sistema de ejecución de sentencias en lo contencioso-administrativo: reflexiones a raiz de la legislación y la jurisprudencia. La realidad cotidiana: ejemplos prácticos de modelos de "inejecución"
} 
E1 Real Decreto de 24 de septiembre de 1889, aprobado por el entonces Ministro de Gracia y Justicia, José Canalejas, intenta asegurar de forma efectiva la inamovilidad de los jueces. Y ello porque, como manifestaba la parte expositiva de dicha norma, "las garantias de inamovilidad consignadas en la ley orgánica del Poder judicial amparan hoy tan sólo a los funcionarios que ingresaron en la carrera mediante oposición, con lo que más de las cuatro quintas partes de nuestros Jueces y Magistrados pueden ser destituidos, suspensos y trasladados sin alegación siquiera de causa." De ahí que el artículo 1 del Real Decreto extendiese a quienes no ingresaron en la carrera judicial mediante oposición las garantías de inamovilidad contempladas en la ley de 15 de septiembre de 1870.

En plena agonía del régimen canovista, es precisamente en el año de la triple crisis (institucional, militar, laboral) cuando mediante Real Decreto de 18 de mayo de 1917 se crea el Consejo Judicial, órgano encargado del "examen $y$ depuración de las condiciones personales de todos los individuos de las Carreras Judicial y Fiscal y de sus Auxiliares", según disponía el artículo 1 de dicha norma reglamentaria. Su composición, sin embargo, desbordaba el ámbito estrictamente judicial, pues integraban dicho Consejo el Presidente del Tribunal Supremo, el Fiscal y un Magistrado de dicho Tribunal, el Decano del Colegio de Abogados de Madrid, el de la Facultad de Derecho de la Universidad Central, el Presidente de la Real Academia de Jurisprudencia y un Vocal de la Comisión general de Codificación ${ }^{60}$; el Secretario sería nombrado y separado por el Gobierno a propuesta del Consejo entre funcionarios de la Carrera judicial y fiscal con la categoría de Magistrados de Audiencia Territorial, Jefes de Sección de la Subsecretaria del Ministerio de Gracia y justicia y Secretarios de la Sala de Gobierno del Tribunal Supremo.

No obstante, el Consejo Judicial previsto en el citado Real Decreto no llegó a constituirse, pues dos meses más tarde, un Real Decreto de 18 de julio de 1917 derogaba el anterior.

de sentencias, publicado en el número 40 (octubre 2015) de la Revista General de Derecho Administrativo, Iustel.

60 El artículo 2 del Real Decreto establecía la prohibición de que los vocales de dicho Consejo ejercieran la Abogacia, y para el supuesto que alguno de ellos tuviese la condición de abogado en ejercicio, se establecían en el citado precepto normas de sustitución: "el Decano del Colegio de Abogados, por los ex Decanos, comenzando por el antecesor del sustituido y asi sucesivamente. En defecto de éstos, o porque todos ejercieran la profesión, será propuesto por la Junta de gobierno un Abogado del Colegio que no ejerza y que durante el tiempo que haya ejercido hubiera completado las condiciones para poder ser nombrado Magistrado del Tribunal Supremo en el turno cuarto de los establecidos por el artículo 144 de la ley Orgánica. Al Decano de la Facultad de Derecho le sustituirán los Catedráticos numerarios de dicha Facultad por el orden de antigüedad, y al Presidente de la Real Academia de Jurisprudencia los ex Presidentes, comenzando por el antecesor del que desempeñe el cargo, y su no hubiera ninguno en condiciones, por el que sea o haya sido vicepresidente primero, observándose el mismo orden de sustitución." 


\subsection{La Junta Organizadora del Poder Judicial de $1923^{61}$.}

\subsubsection{El advenimiento de la Dictadura.}

Conviene indicar que el golpe de Estado protagonizado por el general Miguel Primo de Rivera y Orbaneja el 13 de septiembre de 1923 no fue un estallido espontáneo o inesperado, sino que llevaba larvándose desde hacía tiempo, más que nada por la incapacidad del sistema canovista para regenerarse avanzando hacia un sistema parlamentario. El desfase entre la España oficial y la España vital adquiría tintes tan dramáticos que el propio autor de la distinción, José Ortega y Gasset, publicaba el día 20 de enero de 1920, en el diario El Sol, un artículo titulado significativamente La hora de Hércules, y en la que apuntaba a la inevitabilidad de un gobierno militar ante la degradación de la vida políticoconstitucional española, algo que hacía en los siguientes términos:

"Todo hombre democrático, es decir, todo hombre que respete la idea del derecho debe preferir ver suspendida la legalidad a verla burlada y escarnecida. He aqui por qué nosotros pedimos la constitución de un gobierno militar. Si creyéramos que existian en la politica civil fuerzas suficientes para restaurar la ley, a ellas acudiriamos. Pero, exentos de proximidades sentimentales con los grupos politicos, libre nuestro juicio y abierta nuestra mirada sobre la verdad española, hallamos que esas fuerzas no existen.

Conste, pues, que no se nos da a elegir entre un Gobierno militar y un Gobierno civil. La realidad es que los ciudadanos tienen que optar entre un Gobierno responsable de militares o un Gobierno irresponsable de los mismos. En tal situación, no concebimos que pueda vacilar nadie, $y$ menos todavia comprenderiamos que cupiese hallar parlamentarios dispuestos a formar nuevamente Gobiernos esquiroles [...]

Antes de que llegasen las horas floridas de la Grecia clásica, fue preciso, según la leyenda, destruir los monstruos y limpiar los establos de Augias. Este duro menester no era faena para Platón: tuvo que cumplirlo Hércules."62

Y todo parecía apuntar al general Aguilera como ese Hércules redivivo a quien correspondería la limpiar los establos de la vida política española, pero un escasamente afortunado encontronazo con el politico José Sánchez Guerra truncó sus aspiraciones, y todos los ojos se volvieron entonces hacia Miguel Primo de Rivera y Orbaneja, miembro de un ilustre linaje de militares, para que asumiese el rol de "cirujano de hierro". El 13 de septiembre de 1923 tiene lugar el pronunciamiento militar y tres días más tarde aparece publicado en la Gaceta el Real Decreto de 15 de septiembre de 1923, en virtud del cual se suprime el Consejo de Ministros y se nombra presidente del directorio militar a Primo de Rivera. En la exposición que antecede al articulado, se insiste en el carácter provisional y transitorio de la medida:

61 Es de lectura obligada para esta breve etapa histórica el trabajo de Francisco Javier DE BENITO FRAILE, La independencia del Poder Judicial durante la dictadura de Primo de Rivera (1923-1926). Realidad o ficción, Anuario de Historia del Derecho Español, LXXXV, 2015, p. 344375 .

62 José ORTEGA Y GASSET, Obras completas III, Taurus-Revista de Occidente, 2005, p. 319320. 
"V.M. sabe bien que ni yo, ni las personas que conmigo han propagado y proclamado el nuevo régimen, nos creemos capacitados para el desempeño concreto de carteras ministeriales, y que era y sigue siendo nuestro propósito constituir un breve paréntesis en la marcha constitucional de España, para restablecerla tan pronto como, ofreciéndonos el pais hombres no contagiados de los vicios que a las organizaciones politicas imputamos, podamos nosotros ofrecerlos a V.M. para que se restablezca pronto la normalidad."

Y lo cierto es que el Directorio Militar contó con un inmenso apoyo, desde el Partido Socialista Obrero Español hasta las grandes capas de la población, incluyendo, por supuesto, a una gran parte de la magistratura; los únicos que mostraron una tibia disconformidad fueron, precisamente, los líderes de los partidos dinásticos, por cuanto desalojados abruptamente del poder se sintieron en la obligación de elevar una protesta. Buena prueba de esa aceptación popular del nuevo régimen se explicita en un artículo, titulado significativamente Sobre la vieja politica, publicado el 23 de noviembre de 1923 en el diario El Sol, donde José Ortega y Gasset indicaba:

"Esta idea, que el primer manifiesto expresaba, coincide exactamente con la opinión pública. La masa española piensa, en efecto, que la culpa de los males patrios la tienen los políticos, y que, extirpados éstos, el pueblo español vivirá feliz y en buen orden. Si el movimiento militar ha querido identificarse con la opinión pública y ser plenamente popular, justo es decir que lo ha conseguido por entero."63

\subsubsection{E1 Decreto de 2 de octubre de 1923.}

La Gaceta del día 3 de octubre de 1923 publica un Decreto aprobado el día anterior en virtud del cual se crea una Junta Inspectora del Personal Judicial, integrada por tres magistrados del Tribunal Supremo. La medida se califica explicitamente como "extraordinaria", y tiene como objetivo "seleccionar rápida y enérgicamente el personal, al que por ministerio de la ley se le considera tan augusta misión, separando a todos aquéllos -los menos sin duda-que con desdoro de la colectividad a que pertenecen, no son merecedores por su impura actuación, por su escasa moral profesional, de que se sometan a su juicio y resolución los derechos de los que acuden en demanda de justicia a los Tribunales."

La Junta, de carácter "transitorio" en su carácter según el artículo 1 del Decreto insistia, estaría compuesta por tres Magistrados del Tribunal Supremo y un Secretario, y tendría como misión "examinar, revisar y fallar cuantos expedientes y procedimientos de todas clases se hayan incoado durante los cinco últimos años para exigir responsabilidad civil o criminal a Jueces y Magistrados de todas las categorias, cualquiera que sea el estado en que se encuentren las diligencias, la resolución que haya recaido en ellas y aunque estén archivadas." Sus resoluciones tenían un carácter decisorio, y sus fallos "dictados conforme al recto juicio de los individuos" que la integraban. Se establecía un plazo "improrrogable" de dos meses para el desempeño de las funciones encomendadas.

Se trataba, por tanto, de revisar los expedientes tramitados en los últimos cinco años frente a miembros de la judicatura, aunque se hubiese dictado resolución o se encontrasen archivados. Las decisiones de la junta serían

\footnotetext{
63 José ORTEGA Y GASSETT, Obras completas III, op. cit., p. 550.
} 
decisorias, si bien las resoluciones se trasladarian al Presidente del Gobierno "para cumplimiento y publicación del fallo, y asi de modo inmediato se procederá a la ansiada depuración."

La tarea se efectuó cumplidamente, si bien tras la concesión de una prórroga del plazo máximo para resolver, debido al elevado número de asuntos. De todas formas, el resultado final no se caracterizó por un excesivo rigorismo, por cuanto "el número de miembros corregidos con distintos tipos de sanciones ascendió a la suma de 47, lo que significaba un porcentaje del 4,45\% de entre todas las categorías [...] A juicio de Antonio Agúndez, habida cuenta del extenso escalafón, no se acredita el excesivo rigor achacado por los enemigos de la dictadura, aunque no debemos olvidar que se trataba de expedientes abiertos en los últimos cinco años $y$ por tanto incoados bajo un régimen politico que el Directorio pretendia erradicar, $y$ con intereses y planteamientos ideológicos diferentes."64

\subsubsection{El Decreto de 20 de octubre de 1923.}

La Gaceta del día 21 de octubre de 1923 publica un Real Decreto firmado el día anterior en la localidad de La Ventosilla, y en virtud del cual se crea la denominada Junta Organizadora del Poder Judicial como órgano de gobierno de los jueces. Dicha Junta estaría integrada por jueces elegidos entre los propios integrantes de la magistratura, que sería la encargada de tramitar y resolver todos los asuntos relativos o que afectasen a la magistratura. El preámbulo del Decreto explicitaba su fin último:

"Es la Justicia institución que afecta a todos los individuos, pues todos tienen que acudir a los Jueces y Tribunales en defensa de su integridad personal o de su honor.

Al par que la depuración de los funcionarios judiciales, se impone la independencia de ellos, en relación con los Poderes públicos, para que no resulten ligados ni siquiera por el agradecimiento, que para administrar justicia realmente es necesario prescindir de simpatias, afectos y gratitudes, de todo, en fin, lo que no sea poner la mira en la ley rectamente interpretada, y en la moral estrictamente cumplida.

Confiamos a la propia Magistratura su depuración, su reforma y su régimen, porque estamos seguros de ella misma, pero alejándola de toda intervención politica, de todo aquello que desgraciadamente ha perturbado su vida y la seguiria perturbando si no viniesen intervenciones como las de ahora, como la de este Decreto..."

Así, pues, se crea la Junta Organizadora del Poder Judicial, integrada por dos Magistrados del Tribunal Supremo, un Magistrado de Audiencia Territorial, otro de Audiencia provincial y un juez de primera instancia "o, en lugar de cualquiera de ellos, los funcionarios correspondientes del Ministerio fiscal de iguales categorias a las designadas". El miembro más antiguo en la carrera judicial de entre los que integrasen la junta sería el presidente, y el de menor categoría sería el secretario. La elección de los jueces y magistrados que integraban la junta se

64 Emilio Javier DE BENITO FRAILE, La independencia del Poder Judicial durante la Dictadura de Primo de Rivera, op. cit., p. 349; en las páginas 367 a 369 se contiene un cuadro con las correcciones disciplinarias impuestas por la Junta. 
haría por elección entre los propios jueces, si bien "cada uno de los electores votará solamente a los de su categoría respectiva", si bien emitiria dos papeletas, uno para efectivo y otro para suplente. Como dato curioso, el Decreto imponía a los jueces la obligación de votar "si no estuviesen imposibilitados". Se trataba, por tanto, de un órgano integrado única y exclusivamente por miembros de la judicatura, lo que le apartaba del articulado en 1917.

En cuanto a las atribuciones, la meritada Junta sería la competente para acordar "todas las propuestas para nombramientos, ascensos, traslados y permitas, desde la categoría de jueces de entrada a la de Presidente de Sala inclusive del Tribunal Supremo." Con todo, el nombramiento formal correspondia al Ministro de Justicia a quien se otorgaba, de acuerdo con el Gobierno, la posibilidad de devolver las propuestas efectuadas por la Junta, si bien en este caso ésta efectuaría otra designación frente a la cual no cabría oponerse. Por tanto, sobre el papel, se consagraba un verdadero autogobierno judicial, por cuanto las competencias integras relativas a las provisiones, traslados y vacantes las ejercía la Junta, integrada por jueces y magistrados elegidos por los propios integrantes de la judicatura.

\subsubsection{Funcionamiento del sistema.}

Hasta el momento, hemos reflejado exclusivamente las previsiones normativas aprobadas por el Directorio militar, pero los antecedentes históricos si algo aconsejan es no tomar como una especie de dogma de fe las palabras impresas en los boletines oficiales, dado que en numerosas ocasiones se diluyen como azucarillo en el agua de la realidad cotidiana. Por ello, conviene verificar si en el presente caso, las medidas adoptadas en pro de instituir un verdadero autogobierno de los jueces traspasaron los umbrales de la Gaceta.

Para un estudio del funcionamiento real del sistema, hemos de remitirnos forzosamente al detallado estudio de Emilio Javier de Benito Fraile. Pronto surgieron críticas de la propia judicatura debido a la forma de elección, en cuanto postergaba injustificadamente a los jueces en beneficio de los magistrados, algo injusto habida cuenta que aquéllos únicamente podían emitir su voto para el vocal representativo de dicha categoria, queja ésta que se reproduciría en numerosas ocasiones, junto con propuestas que buscaban introducir el sistema de ascenso por méritos en lugar de la aplicación pura y dura del principio de antigüedad65.

En lo que se refiere al aspecto de la injerencia del ejecutivo en el ámbito de la magistratura, parece ser que, paradójicamente, la misma no fue tan intensa como pudiera extraerse de la naturaleza del régimen. Al margen de episodios aislados, como el tragicómico episodio de La Caoba:

"los choques entre el poder ejecutivo y la alta magistratura no parecen ser frecuentes, según se puede deducir de la documentación recogida en los archivos [...] En los ámbitos inferiores de la judicatura, la situación que encontramos es sensiblemente diferente; posiblemente como consecuencia de la mayor proximidad, conocimiento $y$ contacto entre los representantes del poder judicial, los delegados

65 Emilio Javier DE BENITO FRAILE, La independencia del Poder Judicial durante la Dictadura de Primo de Rivera, op. cit., p. 355-358. 
del poder politico en dichos territorios, asi como los propios ciudadanos [...] son, por tanto, numerosas las denuncias de los propios vecinos, quienes al no ver atendidas sus expectativas en una resolución judicial que les afecta, aprovechan este momento de cambio politico para descalificar al juez y solicitar su relevo. Otras veces se trata de los propios gobernadores civiles y delegados del gobierno, quienes al no verse complacidos por los representantes de la judicatura en su territorio, o no ser afines al régimen politico dominante, arremeten contra los mismos, presentando denuncias a sus superiores, buscando el que sean sustituidos por personas más próximas a sus intereses."66

Sin embargo, para Enrique Orduña Rebollo, Primo de Rivera intervino activamente con la finalidad de "ejercer el control del poder judicial"67. No obstante, conviene tener en cuenta que dicho autor sostiene que "el control del Poder judicial se produjo posteriormente, por medio de las destituciones y traslados forzosos de los magistrados, lo que rompia el esquema de la inamovilidad de los jueces y su acceso a la carrera diseñado en 1812 y consolidado a lo largo del siglo $X I X^{\prime \prime}$, y ya hemos aportado ejemplos suficientes de lo que verdaderamente implicaba en el mundo de los hechos la "inamovilidad" de la magistratura diseñada en los textos legales.

\subsubsection{El final de la experiencia: el Consejo Judicial de 1926.}

Suprimido en 1925 el Directorio Militar y reinstaurado un gobierno civil, bajo la presidencia igualmente de Primo de Rivera, la Gaceta del 22 de junio de 1926 publica un Real Decreto fechado el dia anterior que disuelve la Junta Organizadora del Poder Judicial, sustituyéndola por un Consejo Judicial como "organismo superior del Poder judicial en el orden gubernativo y en el disciplinario, salvo el Tribunal Supremo en pleno o la Sala de Gobierno del mismo, en cuanto sea de la exclusiva competencia de éstos." Dicho consejo lo integraban nueve miembros, todos ellos procedentes de la carrera judicial, algunos de ellos natos y otros, hasta completar el número, serian nombrados "libremente entre los funcionarios de la carrera judicial con destino permanente en Madrid, por Real decreto acordado en Consejo de Ministros a propuesta del de Gracia y Justicia." Es decir, que aun cuando se atribuía al meritado Consejo las funciones de gobierno de la magistratura, se reintroducía sibilinamente la influencia del ejecutivo a través de la designación por éste de parte de los vocales.

A la hora de analizar esta normativa, conviene no perder de vista las lúcidas reflexiones de Francisco Sosa Wagner, que encubre con el divertido manto de su brillante estilo literario la amargura de su reflexión proyectándola sobre las previsiones constitucionales de 1978:

66 Emilio Javier DE BENITO FRAILE, La independencia del Poder Judicial durante la Dictadura de Primo de Rivera, op. cit., p. 361-363. No tienen desperdicio los Informes reservados acerca de los Jueces Municipales, que el autor sistematiza en un cuadro reproducido como Anexo II al artículo. Entre las observaciones que se plantean a los diversos jueces municipales, podemos encontrar las siguientes: "está incondicionalmente al lado de los caciques del antiguo régimen, pernicioso"; "denunciado por estupro, irreligioso, cacique enemigo. Tiene secretario estafador inhabilitado"; "se vale del cargo para fines lucrativos"; "no tiene condiciones para el cargo y labora contra el régimen"; "de dudosa moral, muy politico y parcial; opuesto a este régimen."

67 Enrique ORDUÑA REBOLLO, Historia del Estado español, op. cit., p. 801-803. 
"Llegamos a creer en mi generación que, con el Consejo General del Poder Judicial [...] habiamos logrado el rien ne va plus de autogobierno judicial. Nadie imaginaba en los años ochenta del siglo XX, cuando se cocinaba este, en medio de ardores "progresistas" y excesos teológico-constitucionales, que la rechoncha sombra del general Primo de Rivera -y de la revolución mexicana- se proyectaba sobre los trabajos de la democracia española de finales del siglo XX."68

\section{IV.- LA SEGUNDA REPÚBLICA Y EL PODER JUDICIAL.}

Llegamos así a unos años que, en acertadísimas palabras de Sosa Wagner, "tanta nostalgia producen en la actualidad en ambientes que podriamos llamar tiernos en materia de saberes y lecturas", época y sistema cuyo tratamiento del poder judicial "reprodujo el modelo que venía de la monarquía, con leves retoques."69

Apenas transcurrido un mes desde la proclamación de la República, mediante Decreto de 19 de mayo de 1931 se deroga de forma expresa el Real Decreto de 21 de junio de 1926, declarando disuelto el Consejo Judicial. La exposición de motivos establecía que "constituye un deber del Gobierno el hacer desaparecer los organismos que fueron creados durante los pasados Gobiernos dictatoriales sin justificación suficiente, organismos a los cuales se atribuyó a veces el desempeño de funciones que con anterioridad a su creación se venian cumpliendo con regularidad o estaban previstas en las leyes", y justifica la medida con una afirmación sorprendente, pues sostiene que dicho Consejo: "no cuenta ni con el apoyo de la inmensa mayoría de la Magistratura, que, por el contrario, le condena y pide su inmediata disolución". La medida se sumaba a tantas otras disposiciones que pretendian rectificar abiertamente la obra legislativa de la Dictadura de Primo de Rivera, aunque en este caso justificando su adopción en el propio disgusto que el Consejo Judicial despertaba en la propia magistratura.

El texto constitucional de 1931 pretendió romper definitivamente con el modelo constitucional decimonónico y situar a nuestro país en la órbita de los nuevos esquemas del constitucionalismo surgidos en el periodo de entreguerras $^{70}$. Sin embargo, la Constitución de 1931 no logró articular un sistema político coherente, y sus disfunciones fueron, en no poca medida, causa del debilitamiento del sistema ${ }^{71}$.

68 Francisco SOSA WAGNER, La independencia del juez ¿Una fábula?, op. cit., p. 55.

69 Francisco SOSA WAGNER, La independencia del juez, ¿una fábula?, op. cit., p. 56. Del mismo autor, Juristas en la Segunda República. 1. Los iuspublicistas, Marcial Pons, 2009, obra cuya primera parte (páginas 13-77) ofrecen una visión del periodo republicano muy alejada de la deliberada y absurda mitificación que estamos acostumbrados a ver recientemente en ambientes institucionales y mediáticos.

70 Joaquín VARELA SUANZES-CARPEGNA, La Constitución española de 1931. Reflexiones sobre una Constitución de Vanguardia, trabajo incluido en Politica y Constitución en España (1808-1978), op. cit., p. 735-750. Para una consulta del proceso constituyente, véase La Constitución de 1931, volumen VIII de la colección Las Constituciones españolas, Iustel, 2009.

71 Considero imprescindibles dos trabajos debidos a Joaquín TOMÁS VILLARROYA: La formación de gobierno durante la segunda república, Revista de Estudios Politicos número 204 (1975). 49-91; Presidente de la República y Gobierno: sus relaciones, Revista de Estudios Politicos (Nueva Época) núms 31-32 (enero-abril 1983), p. 71-99, y 
Cabe indicar que, por primera vez, se distinguía de forma explícita entre justicia ordinaria y justicia constitucional, encomendando esta última al Tribunal de Garantias Constitucionales, órgano regulado en el Título IX de la Constitución, $\mathrm{y}$ al que se encomendaba no sólo funciones de esa naturaleza (recursos de inconstitucionalidad y de amparo, conflictos de competencias), sino un par de cuestiones que en principio debieran corresponder a la justicia ordinaria, como la responsabilidad criminal del Presidente de la República, del Consejo y los Ministros, así como la del Presidente y los Magistrados del Tribunal Supremo y el Fiscal General de la República ${ }^{72}$. No obstante, la composición de dicho organismo no era precisamente la más adecuada, pues acentuaba su politización ${ }^{73}$.

La justicia ordinaria se regulaba en el Título VII. Ya para empezar, la Constitución tenía el mismo recelo hacia la denominación "poder judicial" que las constituciones moderadas del siglo XIX, pero tampoco quiso mantener la nomenclatura "Administración de Justicia", así que optó por un tertium genus limitándose a intitular la regulación como "Justicia".

En lo que se refiere a los jueces, se reconocía que los mismos "son independientes en su función" (artículo 94.2) y que los mismos "no podrán ser jubilados, separados ni suspendidos en sus funciones, ni separados de sus puestos, sino con sujeción a las leyes, que contendrán las garantias necesarias para que sea efectiva la independencia de los Tribunales" (artículo 98). Por su parte, el Presidente del Tribunal Supremo seria designado por el Jefe del Estado, a propuesta de una Asamblea constituida por la forma que determine la ley, y su mandato seria de 10 años (artículo 96). No se requería para ello ser magistrado, sino ser mayor de 40 años y licenciado en Derecho.

La letra de la ley era bien clara, y únicamente queda por verificar si su espíritu se trasladó a la práctica. Y lo cierto es que en este punto los dirigentes republicanos mostraron tan pocos escrúpulos como los partidos dinásticos durante el siglo XIX y primer tercio del XX, dado que no tuvieron inconveniente alguno a la hora de intervenir en el mundo judicial para "republicanizarlo". Pero cuando los radicales y cedistas se alzaron con el poder en 1933 no consideraron moralmente reprochable imitar a sus predecesores. En acertadas palabras de Francisco Sosa Wagner, "las intromisiones en la carrera judicial de todos los gobiernos republicanos -de cualquiera de los bienios y no digamos del Frente Popular- fueron constantes [...] Todo ello demuestra el entrometimiento politico permanente en las instancias judiciales. Puede decirse que el articulo 98 de la

72 Un reciente y magnífico estudio que, aún cuando tiene por objetivo último analizar la dogmática de los derechos fundamentales, desborda la materia ofreciendo un análisis pormenorizado del Tribunal de Garantias Constitucionales, es el debido a Pablo ÁLVAREZ BERTRAND, El Tribunal de Garantias Constitucionales como órgano de tutela de los derechos fundamentales, KRK ediciones, 2017.

73 El artículo 122 del texto constitucional regulaba la composición del Tribunal de Garantias Constitucionales: "Un Presidente designado por el Parlamento (sea o no diputado), el Presidente del Cuerpo Consultivo de la República, dos diputados libremente elegidos por las Cortes, un representante de cada una de las regiones, dos miembros nombrados electivamente por todos los colegios de abogados de la República y cuatro profesores de la facultad de Derecho." 
Constitución, garantizador de la inamovilidad de los jueces, fue infringido con desparpajo en sonadas ocasiones..."74

\section{V.- EL AUTOGOBIERNO DE LOS JUECES EN LA CONSTITUCIÓN DE 1978: EL CONSEJO GENERAL DEL PODER JUDICIAL.}

No es este el momento ni el lugar de abordar in extenso la transición política española y su proyección en el mundo de la justicia, sino que nos centraremos en analizar cómo se reflejó el autogobierno judicial tanto en el anteproyecto de Constitución como en el resultado final.

\subsection{Modelos constitucionales existentes.}

Parece claro que el constituyente español de 1978 tenía dos opciones: bien mantener el sistema tradicional de gestión centralizado en el Ministerio de Justicia, o bien instaurar un modelo en el que el gobierno del poder judicial se desplazase a la propia judicatura, creando o no un órgano colegiado al efecto, dado que esta última opción no es en absoluto necesaria para garantizar dicha independencia judicial ${ }^{75}$.

Parece evidente que tanto los encargados de redactar el proyecto de constitución como las propias Cortes tuvieron en mente los modelos de autogobierno judicial existentes en aquellos momentos en las principales naciones de la Europa continental, pues en el mundo anglosajón la situación es radicalmente distinta ${ }^{76}$.

Los tres modelos básicos que existian en la Europa de finales de 1977 eran el alemán, el francés y el italiano ${ }^{77}$. El alemán no contaba con un sistema de autogobierno judicial propiamente dicho, por cuanto la Comisión Electora de

74 Francisco SOSA WAGNER, Juristas en la segunda república, op. cit., p. 45-47. Según indica Diego ÍNIGUEZ HERNÁNDEZ, "La Ley de 8 de septiembre de 1932 permitió la jubilación forzosa de cualquier juez o magistrado, que se aplicó a una cifra en torno al diez por ciento de los efectivos de la carrera durante el bienio progresista y siguió vigente durante el bienio conservador"; El fracaso del autogobierno judicial, op. cit., p. 158.

75 “...un órgano como el CGPJ no es necesario. No lo exige el principio de separación de poderes; ni el sistema americano, ni el inglés, ni el alemán, ni los países escandinavos lo tienen; y en realidad, solamente ha resultado un éxito en Italia, pues los órganos semejantes, portugués o francés tienen competencias limitadas"; Diego ÍNIIGUEZ HERNÁNDEZ, El fracaso del autogobierno judicial, op. cit., p. 91

76 En Estados Unidos, por ejemplo, el presidente del Tribunal Supremo o chief justice es nombrado, como todos los jueces y empleados federales, por el Presidente de los Estados Unidos, con el famoso advise and consent senatorial. El chief justice es el responsable máximo de la judicatura federal, si bien en 1967 se creó una estructura administrativa de apoyo, el Federal Judicial Center, integrada por miembros de la judicatura federal. Ahora bien, en el sistema norteamericano no existe propiamente una carrera judicial, pues el nombrado para un puesto de nivel inferior en los Juzgados de Distrito o en los Tribunales de Apelación no tiene opción alguna de promocionar, a no ser que el presidente lo proponga para puesto superior. Es lo que ha ocurrido en los últimos años en el Tribunal Supremo, donde todos los jueces (salvo Elena Kagan) han sido previamente jueces de apelación.

77 Nos guiamos en esta materia por los comentarios de José Manuel Serrano Alberca al artículo 122.2 del texto constitucional en Fernando GARRIDO FALLA (ed), Comentarios a la Constitución, Civitas, Madrid, p. 1272-1276. Obra extremadamente útil por cuanto transcribe no sólo los textos de derecho comparado, sino la propia génesis de la elaboración del texto constitucional español. 
Jueces prevista en el artículo 95.2 de la Ley Fundamental de Bonn no estaba integrada por miembros de la magistratura. Ello restringía los modelos sustancialmente a dos: el francés y el italiano.

El Consejo Superior de la Magistratura contemplado en el artículo 65 de la Constitución francesa de 1958 era un órgano de composición heterogénea, presidido por el presidente de la república, e integrado por el ministro de Justicia (que era el vicepresidente nato y, por tanto, quien suplía al presidente en caso de ausencia), y nueve miembros nombrados por el Presidente de la República en las condiciones fijadas por una ley orgánica; en la legislación de desarrollo se estableció que de los nueve miembros, seis pertenecerian a la magistratura, uno provendría del Consejo de Estado y otro dos serían ajenos a la carrera judicial. En cuanto a sus competencias, le correspondía elevar propuestas para el nombramiento de los magistrados titulares en el Tribunal de Casación y para el primer presidente del Tribunal de Apelación así como expresar su opinión sobre las propuestas del ministro de Justicia en cuanto al nombramiento de otros magistrados titulares y ser consultado en el ejercicio de la prerrogativa de gracia. Ejercía igualmente como órgano encargado de resolver los expedientes disciplinarios de los magistrados titulares, si bien en este supuesto los dos integrantes de composición política (presidente de la República y ministro de Justicia), no podrian asistir a las sesiones.

Pero, sin duda alguna, el modelo que influyó a los constituyentes españoles en 1978 fue el Consejo Superior de la Magistratura, regulado en los artículos 104 y 105 de la Constitución italiana de 1947. A dicho órgano, descrito como "autónomo e independiente de cualquier otro poder" se le atribuian constitucionalmente "la admisión, la asignación, el traslado, los ascensos y las medidas disciplinarias relativas a los magistrados." Ello implicaba un grado de autogobierno mayor que el otorgado al Consejo Superior de la Magistratura francés, que en la mayor parte de los casos únicamente tiene funciones de simple propuesta o meramente consultivas o de informe previo. El Consejo Superior de la Magistratura lo presidía el presidente de la República, y serían miembros por derecho propio el Primer Presidente y el Fiscal del Tribunal Supremo. Dos tercios de sus miembros serian elegidos por los magistrados, y un tercio por el Parlamento "entre profesores numerarios de materias juridicas y abogados que cuenten con más de quince años en el ejercicio profesional." El mandato de sus integrantes sería de cuatro años, y no serian inmediatamente reelegibles.

Parece claro, pues, que en la España del período constituyente que culminó en el texto de 1978 el referente inmediato para trasladar el autogobierno judicial a la norma suprema fue el Consejo Superior de la Magistratura existente en Italia, aunque con algunas peculiaridades que le apartan del modelo. No obstante, el profesor Sosa Wagner destaca en su ensayo sobre la independencia judicial una curiosa circunstancia al respecto:

"la inexistencia de un debate a fondo y general entre los miembros de la ponencia acerca de la criatura a la que estaban dando cuerpo y alma. Un debate sobre sus posibles antecedentes en la Historia de España y, más lógico aún, su parentesco con los modelos de Derecho comparado, un topi de estudio al que los juristas somos muy aficionados -todos los miembros de la ponencia eran juristas- $y$ 
que habria sido imprescindible porque las originalidades en estos asuntos deben evitarse."78

\subsection{Del Anteproyecto al Texto Constitucional de 1978.}

\subsubsection{El Anteproyecto y su tramitación en el Congreso de los Diputados.}

El Anteproyecto de Constitución, publicado en el Boletín Oficial de las Cortes correspondiente al día 5 de enero de 1978 abordaba en el segundo y tercer apartado del artículo 112 la regulación del Consejo General del Poder Judicial, lo que efectuaba en los siguientes términos:

2. El Consejo General del Poder Judicial es el órgano de gobierno de la Administración de Justicia. La ley orgánica establecerá su estatuto y funciones, en particular en materia de nombramientos, ascensos e inspección. Sus miembros estarán sujetos al mismo régimen de incompatibilidades que el de los miembros del Tribunal Constitucional.

3. El Consejo General del Poder Judicial estará integrado por el Presidente del Tribunal Supremo, que lo presidirá, y por veinte miembros ${ }^{79}$ nombrados por el Rey, doce de ellos a propuesta y en representación de las distintas categorias judiciales y ocho a propuesta del Congreso de los Diputados, entre juristas de reconocida competencia con más de quince años de ejercicio en su profesión.

Dicho precepto fue objeto de varias enmiendas en el Congreso de los Diputados. En cuanto a la denominación, Raúl Morodo y Laureano López Rodó favorecían mutar la nomenclatura de dicho órgano, hablando en su lugar de "Consejo General de la Justicia."

Interesa destacar la número 435 presentada por el Grupo Parlamentario Socialista (que coincide con la número 293 presentada por el Grupo Parlamentario Socialistas de Cataluña), porque revela ya lo que será una constante en su proceder en la materia. Aun cuando mantiene en veinte el número de miembros, pretende que sean únicamente ocho los que sean " $a$ propuesta y en representación de todos los jueces y magistrados" y doce "a propuesta de tres quintas partes del Congreso de los Diputados", justificando la modificación del número de miembros propuestos a instancias del Parlamento "porque parece conveniente un mayor control por parte de éste." El Grupo Parlamentario Vasco se situó, en cuanto al número de miembros, en un punto intermedio entre el proyecto y la postura de los socialistas, por cuanto en su enmienda número 643 pretendió repartir los veinte miembros de forma equitativa, diez a propuesta de los jueces y magistrados y los otros diez a propuesta del Parlamento.

La enmienda número 544, presentada por Raúl Morodo como portavoz del Grupo Mixto, pretende incluir la duración del mandato (que fija en cinco años) y respecto a los doce vocales de procedencia judicial incluye la precisión que fuesen "elegidos democráticamente por los miembros de las distintas carreras judiciales" y

78 Francisco SOSA WAGNER, La independencia del juez, ¿una fábula?, op. cit., p. 77.

79 "fueron doce inicialmente en la discusión constitucional, pero una enmienda de Gregorio PecesBarba elevó el número. Es claro que el profesor Peces-Barba tuvo momentos de mayor lucidez que éste en su vida política y parlamentaria"; Francisco SOSA WAGNER, La independencia del Juez, ¿una fábula? op. cit., p. 89-90. 
que los ocho a elegir por el Congreso lo fuesen con arreglo al sistema de representación proporcional, así como que los acuerdos adoptados por el Consejo se residenciasen ante el Tribunal Constitucional.

La enmienda número 691 presentada por Laureano López Rodó introduce una interesantísima precisión en cuanto a los doce vocales, que no serian " $a$ propuesta y representación" de las distintas categorías judiciales, sino "pertenecientes" a ellas; la mutación, aparentemente menor, no es baladí pues en el primer caso no se explicitaba que los vocales representantes de los jueces hubieran de pertenecer a la magistratura, algo que sí quedaba recogido con la enmienda de López Rodó. Pero el catedrático de Derecho administrativo y antiguo comisario del Plan de Desarrollo va más allá y demuestra adelantarse a los acontecimientos a la hora de justificar su proceder: "admitir que el Consejo General, que va a decidir o influir, según parece, en el nombramiento y ascensos, pueda estar integrado por Jueces y Magistrados "a propuesta y en representación de las distintas categorias judiciales", se presta a introducir en estas distintas carreras el antagonismo y la desunión, a la vez que el partidismo politico."

La enmienda 695 del comunista José Solé y Barberá introduce el número de años del mandato de los vocales, que fija en cuatro, y en cuanto a los ocho vocales propuestos a instancias del Parlamento, especifica que serian "en representación proporcional de los grupos parlamentarios", eliminando el requisito de quince años de experiencia exigida, algo que razona explicitando algo que la práctica acaecida con posterioridad al año 1985 se encargará de demostrar: "la razón de la designación de los miembros no judiciales, que sólo debe obedecer a la razón politica de su designación y a su específica competencia sin limitación del tiempo que hayan precisado para adquirirla."

Por tanto, como hemos visto, las enmiendas se centraron, sobre todo en precisar el mandato de los vocales y, sobre todo, en una lucha titánica de los socialistas por incrementar los de procedencia parlamentaria.

La Ponencia acepta parte de las enmiendas referidas, sobre todo, a la duración del mandato de los vocales, pero rechaza la mayoría de las objeciones presentadas. Así, los apartados segundo y tercero del que pasará a ser el artículo 114 pasan a tener el siguiente tenor:

2. El Consejo General del Poder Judicial es el órgano de gobierno del mismo. La ley orgánica establecerá su estatuto y el régimen de incompatibilidades de sus miembros y sus funciones, en particular en materia de nombramientos, ascensos, régimen disciplinario y duración de su mandato.

3. El Consejo General del poder judicial estará integrado por el Presidente del Tribunal Supremo, que lo presidirá y por quince miembros nombrados por el Rey, por un periodo de cinco años. Diez entre Jueces y Magistrados, en los términos que establezca la ley orgánica y cinco a propuesta del Congreso de los Diputados elegidos por mayoría de 3/5 de sus miembros, entre juristas de reconocida competencia, con más de quince años de ejercicio de su profesión.

Entre las novedades destacadas, se encuentra que el Consejo ya no es el órgano de gobierno "de la Administración de justicia", sino del poder judicial. En cuanto a su composición, se rebajan los vocales de veinte a quince, se remite al desarrollo mediante ley orgánica el modo de elección de los de procedencia 
judicial y se explicita la mayoría de tres quintos para los de representación parlamentaria.

Tras un intenso debate en el seno de la Comisión de Asuntos Constitucionales y Libertades Públicas, el precepto varía nuevamente su numeración, pues pasa a ser el 116. El apartado segundo se mantiene prácticamente incólume, sin más que añadir la facultad de "inspección" como elemento que habría de regular necesariamente la ley orgánica de desarrollo. E1 apartado tercero eleva de nuevo el número de vocales en veinte, de los cuales doce serian de procedencia judicial y ocho de procedencia parlamentaria. Texto que es el finalmente aprobado finalmente por el Congreso de los Diputados

\subsubsection{El Anteproyecto en el Senado y en la Comisión Mixta.}

La regulación del Consejo General del Poder Judicial no sufre otra modificación en el Senado que la estrictamente numérica, dado que el precepto pasa a ser el artículo 121. La única mutación en cuanto al contenido radicó en dividir los ocho vocales de procedencia parlamentaria, pues se explicita que cuatro de ellos serían a propuesta del Congreso de los Diputados y otros cuatro a propuesta del Senado, elegidos en ambos casos por mayoría de tres quintos. Dicha redacción se traslada en su integridad al Dictamen de la Comisión Mixta Congreso-Senado sobre el proyecto de Constitución, donde el precepto pasa a ser ya el artículo 122, numeración y contenido que pasaron al texto definitivo.

\subsection{Breve referencia a la evolución posterior.}

Ratificada por el pueblo español la Constitución de 1978 y una vez que la misma entra en vigor, se sucedieron tres modelos sucesivos de autogobierno judicial, que Diego Íñiguez Hernández califica de corporativo (el de 1980), parlamentario (el de 1985) y el "modelo con elementos corporativos nuevos, pero al fin predominantemente parlamentario" (el de 2001) ${ }^{80}$.

La Ley Orgánica $1 / 1980$ de 10 de enero, del Consejo General del Poder Judicial, ofreció el indispensable desarrollo normativo al artículo 122.2 de la Constitución articulando un modelo corporativo en el cual los doce vocales de procedencia judicial serian elegidos por los propios jueces y magistrados de entre los miembros de la carrera judicial. En lo que se refiere a la composición de dicho órgano, el artículo octavo disponía que los "doce vocales de procedencia judicial serán elegidos entre Jueces y Magistrados pertenecientes a todas las categorias judiciales", precisando que de ellos, tres serían Magistrados del Tribunal Supremo, seis Magistrados y tres jueces. Según el duodécimo artículo, los vocales de procedencia judicial "serán elegidos por todos los Jueces y Magistrados que se encuentren en servicio activo", en unas elecciones en las cuales la circunscripción electoral sería única para todo el territorio nacional y donde los sufragios se efectuarian mediante "voto personal, igual, directo y secreto, admitiéndose el voto por correo", siguiendo el procedimiento regulado en la propia ley orgánica y en su reglamento de desarrollo. En otras palabras, se trataba de respetar que los vocales de procedencia judicial fuesen elegidos por la propia magistratura.

80 Diego ÍÑIGUEZ HERNÁNDEZ, El fracaso del autogobierno judicial, op. cit., p. 221. Es imprescindible para una comprensión global de esta materia la lectura del capitulo quinto de dicha obra. 
La situación dio un giro radical con la llegada al gobierno del Partido Socialista Obrero Español. Dicha formación politica, gracias a la desbordante mayoria absoluta obtenida tras las elecciones del 28 de octubre de 1982, aprobó sin mayores problemas la Ley Orgánica 1/1985 de 1 de julio, Orgánica del Poder Judicial, que pone fin al periodo corporativo para inaugurar otro estrictamente parlamentario, algo en nada sorprendente por cuanto en los debates constitucionales el Partido Socialista ya habia dado muestras de por donde iban los tiros en cuanto a su idea del Consejo. Dicho texto legal corrompió el sistema al detraer a los jueces la facultad de elegir a los vocales de procedencia judicial, atribuyendo su nombramiento a las propias Cortes. La Exposición de Motivos pretendió justificarlo de la siguiente forma:

"Para la elección de los doce miembros del Consejo General del Poder Judicial que, de acuerdo con el artículo 122.2 de la Constitución Española, deben ser elegidos "entre Jueces y Magistrados de todas las categorias judiciales", la Ley, informada por un principio democrático, partiendo de la base de que se trata del órgano de gobierno de un Poder del Estado, recordando que los poderes del Estado emanan del pueblo y en atención al carácter de representantes del pueblo soberano que ostentan las Cortes Generales, atribuye a éstas la selección de dichos miembros de procedencia judicial del Consejo General. La exigencia de una muy cualificada mayoría de tres quintos - a la que la Constitución requiere para la elección de los otros miembros- garantiza, a la par que la absoluta coherencia con el carácter general del sistema democrático, la convergencia de fuerzas diversas y evita la conformación de un Consejo General que responda a una mayoría parlamentaria concreta y coyuntural"

La nueva regulación fue objeto de varias impugnaciones ante el Tribunal Constitucional. En primer lugar, los diversos conflictos interpuestos por el Consejo General del Poder Judicial, entonces presidido por Federico Carlos Sainz de Robles, que, una vez acumuladas, dieron lugar a la Sentencia 45/1985 de 17 de abril, cuyo análisis se circunscribió exclusivamente a dos aspectos: la elección de los vocales de procedencia judicial y la competencia del gobierno para dictar reglamentos sobre el estatuto jurídico de Jueces y Magistrados. El alto intérprete de la Constitución echó balones fuera y desestimó el recurso por cuestiones estrictamente procedimentales, al entender que no existía conflicto alguno, pues los presuntos titulares del derecho de elección serían los jueces y magistrados, no el Consejo propiamente dicho, por lo que se estaria ante un "derecho electoral personal, de carácter subjetivo, cuya actuación no implicaría el ejercicio de potestades de imperio", es decir, ante "una posición subjetiva vinculada a la condición de miembro de carrera integrante del Poder Judicial, pero ajeno del todo al ámbito de los conflictos constitucionales." En esta ocasión, pudo el Tribunal Constitucional escurrir el bulto, aunque no por mucho tiempo.

$\mathrm{Y}$ es que apenas un año después el pudorosamente calificado como legislador negativo hubo de abordar la segunda impugnación, el recurso de inconstitucionalidad que cincuenta diputados de Alianza Popular, encabezados por José María Ruíz Gallardón, interpusieron frente a la nueva Ley Orgánica del Poder Judicial. Poco podría sospecharse en aquellos momentos que veintisiete años después, el siniestro retoño del celebérrimo jurista y diputado promovente del recurso asestaría, ostentando la cartera de Justicia, una puñalada mortal a las tesis defendidas por otro Ruiz Gallardón en 1985. El caso es que en una de las resoluciones más lamentables y vergonzosas del Tribunal Constitucional (y 
eso que dicho órgano, a lo largo de sus ya casi cuatro décadas de penosa actividad, se ha puesto el listón altísimo), la Sentencia 108/1986 de 29 de julio desestima el recurso avalando la constitucionalidad de la ley. Pero, eso sí, al final del decimotercer fundamento jurídico, tras rendirse descaradamente a la apisonadora legislativa, no desaprovechó la ocasión para intentar salvar los muebles dando un picotazo cual abejita, al deslizar esta pía admonición:

"La finalidad de la norma sería así, cabria afirmar de manera resumida, la de asegurar que la composición del Consejo refleje el pluralismo existente en el seno de la sociedad y, muy en especial, en el seno del Poder Judicial. Que esta finalidad se alcanza más fácilmente atribuyendo a los propios Jueces y Magistrados la facultad de elegir a doce de los miembros del CGPJ es cosa que ofrece poca duda; pero ni cabe ignorar el riesgo, también expresado por algunos miembros de las Cortes que aprobaron la Constitución, de que el procedimiento electoral traspase al seno de la Carrera Judicial las divisiones ideológicas existentes en la sociedad (con lo que el efecto conseguido sería distinto del perseguido) ni, sobre todo, puede afirmarse que tal finalidad se vea absolutamente negada al adoptarse otro procedimiento $y$, en especial, el de atribuir también a las Cortes la facultad de propuesta de los miembros del Consejo procedentes del Cuerpo de Jueces y Magistrados, máxime cuando la Ley adopta ciertas cautelas, como es la de exigir una mayoria calificada de tres quintos en cada Cámara (art. 112.3 LOPJ). Ciertamente, se corre el riesgo de frustrar la finalidad señalada de la Norma constitucional si las Cámaras, a la hora de efectuar sus propuestas, olvidan el objetivo perseguido $y$, actuando con criterios admisibles en otros terrenos, pero no en éste, atiendan sólo a la división de fuerzas existente en su propio seno y distribuyen los puestos a cubrir entre los distintos partidos, en proporción a la fuerza parlamentaria de éstos. La lógica del Estado de partidos empuja a actuaciones de este género, pero esa misma lógica obliga a mantener al margen de la lucha de partidos ciertos ámbitos de poder y entre ellos, y señaladamente, el Poder Judicial."

De esta forma, el Tribunal Constitucional pretendió salir del paso emulando no sólo a Poncio Pilatos (por el higiénico lavatorio de manos con la finalidad de trasladar sobre las cabezas de terceros -en este caso del legislativo- la responsabilidad del crimen), sino a Casandra, con el mismo éxito que ésta en cuanto a credibilidad de sus profecías pero, eso sí, sin asumir el mismo coraje, valor y dignidad que la hija de Príamo y Hécuba demostró al lanzar su último augurio justo antes de penetrar en el palacio real de Micenas de donde ya no saldría con vida, tal y como nos cuenta el poeta Esquilo en su magnífica tragedia Agamenón.

El tercero de los modelos, que pretende ser una mezcla de los dos anteriores, es el que se implantó a raíz del denominado Pacto de Estado para la Reforma de la Justicia suscrito en 2001 entre el Partido Popular (entonces en el gobierno) y el Partido Socialista Obrero Español, y articulado a través de la Ley Orgánica 2/2001 de 28 de junio, de Composición del Consejo General del Poder Judicial. Tras la reforma, serian las asociaciones judiciales (o un número de jueces que representase, al menos el $2 \%$ de los que se encuentren en servicio activo), propondrian una lista de hasta el triple de miembros de vocales a elegir (es decir, treinta y seis candidatos), de entre los cuales el Congreso y el Senado deberían escoger los de procedencia judicial ${ }^{81}$.

81 Norma que de forma indisimulada favorecía a las asociaciones judiciales, las grandes beneficiarias, dada la extrema dificultad que un candidato obtuviese las mayorias necesarias exigidas para optar extramuros del asociacionismo judicial. 
Tras la victoria del Partido Popular en las elecciones de 2011, el nuevo ministro de Justicia, Alberto Ruíz Gallardón, en su comparecencia del día 25 de enero de 2012 ante la Comisión de Justicia del Congreso de los Diputados, al exponer las líneas del programa político de su departamento, se refirió expresamente al Consejo General del Poder Judicial. Tras indicar que "no podemos seguir con la imagen de politización de la justicia en España", expresó su intención de "corregir" el sistema para "acabar con esa politización y con esa percepción de politización", lo que únicamente podria hacerse mediante la "modificación del sistema de elección de los vocales del Consejo General del Poder Judicial" para "ir al espiritu de la Constitución", de tal forma que "doce de sus veinte miembros sean elegidos de entre $y$ por jueces $y$ magistrados de todas las categorías."82 Todo apuntaba, pues, a que los vocales de procedencia judicial no sólo serían elegidos de entre los jueces, sino "por" ellos, apuntando a un regreso al sistema corporativo.

No obstante, el valor de las palabras del ministro se demostró tan fiable como la mayoría de los propósitos de año nuevo, pues la Ley Orgánica 4/2013 de 28 de junio, de Reforma del Consejo General del Poder Judicial, en modo alguno se adecuó a lo expresado por el titular de la cartera de Justicia en su comparecencia parlamentaria, pues mantiene el nombramiento parlamentario de los vocales de procedencia judicial.

\section{V.- CONCLUSIÓN.}

La historia constitucional española si por algo se ha caracterizado en lo que a la regulación del poder judicial se refiere, es por acoger en los textos el principio de independencia judicial (ya sea de forma implícita o explícita) mientras que en la práctica se burlaban dichas previsiones de la forma más descarada mediante continuas intromisiones del poder ejecutivo a través de suspensiones, traslados y cesantias. En este punto nada distinguía a conservadores de progresistas, o a monárquicos de republicanos, pues todos ellos concebían la independencia judicial de la misma forma: aplicable única y exclusivamente cuando se hubiese expurgado la judicatura de los desafectos o nombrados por ejecutivos anteriores. Quizá esa circunstancia explique el nulo papel que ha desempeñado la judicatura a la hora de asentar el estado de Derecho en nuestro país, a diferencia de lo que ocurrió en otros como Gran Bretaña o, sobre todo, Estados Unidos. Es muy significativa en este punto la opinión de Jesús González Pérez, quien en las sucesivas ediciones de su magnífico tratado La responsabilidad patrimonial de las Administraciones públicas, ha incluido este jugosísimo párrafo que sintetiza su opinión sobre el particular:

“En este, como en tantos otros aspectos de la estructuración del Estado de Derecho, nuestros jueces no se han caracterizado por su originalidad ni por su audacia. Respetuosos, sumamente respetuosos con quienes, en cada momento, han detentado el Poder, tradicionalmente han sido una rémora en las conquistas del

82 Diario de Sesiones del Congreso de los Diputados, Comisiones, X Legislatura, año 2012, número 25, páginas 3-4. Puede accederse al mismo a través del enlace www.congreso.es/public_oficiales/L10/CONG/DS/CO/CO_025.PDF 
ciudadano en sus relaciones con los Poderes públicos que definen un Estado de Derecho." 83

La Constitución de 1978 pretendió finiquitar tan tristes precedentes consagrando un autogobierno efectivo de la judicatura mediante el injerto en suelo hispano de un Consejo General del Poder Judicial a semejanza del Consejo Superior de la Magistratura italiano. Pero las buenas intenciones de los constituyentes (si es que alguna vez llegaron a tenerlas en lo que al poder judicial se refiere, algo sobre lo cual el humilde redactor de estas líneas, quizá debido a su natural malevolencia, alberga serias dudas) se evaporaron al simple contacto con la realidad, y sobre todo tras la nefasta intervención del Tribunal Constitucional con su Sentencia 108/1986. El daño que dicha resolución ha infligido no sólo al sistema, sino a la propia credibilidad del mismo fue incalculable, y la situación desde entonces ha degenerado hasta tal punto, que los sucesivos procedimientos para la elección de vocales del Consejo General del Poder Judicial se asemejan tanto a un mercado persa que únicamente falta suene como hilo musical la célebre pieza de Ketelbey. Nadie ha descrito la bochornosa situación existente de forma tan certera como Alejandro Nieto en este crudo y descarnado párrafo inserto en su obra más reciente:

"Los partidos politicos tienen atrapados a los jueces a través del Consejo General del Poder Judicial, que es una de las farsas institucionales más cínicas que conocemos. Porque este organismo, que fue creado para asegurar la intangibilidad de los jueces, se ha convertido en un instrumento de su envilecimiento. Partiendo de un pretendido autogobierno se ha terminado en la manipulación más descarada: aqui no se engaña a nadie, todo se hace a la vista del público. No oculta su sumisión a los partidos politicos como estos no ocultan sus intenciones de dominación. Los nombramientos se hacen para cargos importantes -que es su tarea más delicada- se hacen en una feria al aire libre en cuotas escrupulosamente predeterminadas sin necesidad de esconderse en un callejón. Y luego, a la hora de proceder a la provisión de vacantes, vuelve a abrirse el mercadillo y los feriantes se cambian una presidencia por dos vocalias de Sala, un juzgado de instrucción de la Audiencia Nacional por un par de miembros de Tribunales Superiores y al final todos tan amigos, aunque el regateo haya sido duro y se hayan dejado vacantes durante varios años." 84

La politización del Consejo es tan atroz, descarada y explícita que dos hechos concretos y bastante recientes ilustran a la perfección lo descrito en el párrafo anterior. El primero tuvo lugar a mediados del año 2012, cuando un ex ministro socialista (y de Justicia, para mayor escarnio) manifestó públicamente que el Consejo General del Poder Judicial no es una "correa de transmisión de intereses de la corporación judicial, ni un sindicato de jueces", sino "un órgano politico para gobernar a la judicatura y a la magistratura." El uso del adjetivo "politico" y del verbo "gobernar", no dejaban lugar a dudas ni de lo que verdaderamente se pretendía sostener con dicha afirmación ni quienes debian ser los sujetos activo y pasivo de ese "gobierno". Es revelador que ni un solo miembro de la magistratura tuviese a bien no ya rebatir tal aserto, sino elevar

83 Jesús GONZÁLEZ PÉREZ, La responsabilidad patrimonial de las Administraciones públicas, quinta edición, 2009, p. 47

84 Alejandro NIETO, Testimonio de un jurista (1930-2017), op. cit., p. 198. 
mínimamente el tono de voz a modo de tibia protesta. El segundo hecho tuvo lugar un año más tarde cuando, con motivo de su elección como vocal del Consejo General del Poder Judicial, un veterano socialista asturiano a quien a lo largo de su dilatada vida pública únicamente se le conoce su vinculación al mundo de la política, en una entrevista concedida a un diario autonómico de su tierra natal, si bien trató de matizar las afirmaciones de su correligionario en cuanto a la naturaleza del órgano para el que había sido elegido ${ }^{85}$, ofreció una justificación antológica de los motivos que le habian elevado a las cumbres del Olimpo judicial: el éxito de su candidatura se debía a que era "un político honrado"; lo que suponía explicitar, a contrario sensu, un secreto a voces, a saber, que fue su currículum politico, y no profesional, el que se tuvo en cuenta. Al igual que ocurrió en la situación anterior, ningún miembro de la carrera judicial consideró oportuno pronunciarse sobre los "méritos" del candidato.

Por tanto, en lo que se refiere a la independencia del poder judicial, es triste decirlo, nada nuevo hay bajo el sol del régimen constitucional de 1978.

Fecha de envío / Submission date: 11/01/2018

Fecha de aceptación /Acceptance date: 7/04/2018

85 Afirmó, cuando menos de cara a la galería, que dicho órgano "tiene la misión de garantizar la independencia de los jueces" 